\title{
Pervasive sources of isotopically light zinc in the North Atlantic Ocean
}

\author{
Lemaitre Nolwenn ${ }^{1,{ }^{*}}$, De Souza Gregory F. ${ }^{1}$, Archer Corey ${ }^{1}$, Wang Ruo-Mei ${ }^{1,2}$, Planquette Helene ${ }^{3}$, \\ Sarthou Geraldine ${ }^{3}$, Vance Derek ${ }^{1}$
}

${ }^{1}$ Department of Earth Sciences, Institute of Geochemistry and Petrology, ETH-Zürich, Zürich, Switzerland

2 Institute of Earth Sciences, Academia Sinica, Taipei, Taiwan

${ }^{3}$ CNRS, Univ Brest, IRD, Ifremer, LEMAR, F-29280 Plouzane, France

* Corresponding author : Nolwenn Lemaitre, email address : nolwenn.lemaitre@erdw.ethz.ch

\begin{abstract}
:
In this study, we report seawater dissolved zinc ( $\mathrm{Zn}$ ) concentration and isotope composition ( $\mathrm{Zn}$ ) from the GEOTRACES GA01 (GEOVIDE) section in the North Atlantic. Across the transect, three subsets of samples stand out due to their isotopically light signature: those close to the Reykjanes Ridge, those close to the sediments, and those, pervasively, in the upper ocean. Similar to observations at other locations, the hydrothermal vent of the Reykjanes Ridge is responsible for the isotopically light $\mathrm{Zn}$ composition of the surrounding waters, with an estimated source $\mathrm{Zn}$ of $-0.42 \%$. This isotopically light $\mathrm{Zn}$ is then transported over a distance greater than $1000 \mathrm{~km}$ from the vent. Sedimentary inputs are also evident all across the trans-Atlantic section, highlighting a much more pervasive process than previously thought. These inputs of isotopically light $\mathrm{Zn}$, ranging from -0.51 to $+0.01 \%$, may be caused by diffusion out of $\mathrm{Zn}$-rich pore waters, or by dissolution of sedimentary particles.
\end{abstract}

The upper North Atlantic is dominated by low $\mathrm{Zn}$, a feature that has been observed in all $\mathrm{Zn}$ isotope datasets north of the Southern Ocean. Using macronutrient to $\mathrm{Zn}$ ratios to better understand modifications of preformed signatures exported from the Southern Ocean, we suggest that low upper-ocean $\mathrm{Zn}$ results from addition of isotopically light $\mathrm{Zn}$ to the upper ocean, and not necessarily from removal of heavy $\mathrm{Zn}$ through scavenging. Though the precise source of this isotopically light upper-ocean $\mathrm{Zn}$ is not fully resolved, it seems possible that it is anthropogenic in origin. This view of the controls on upper-ocean $\mathrm{Zn}$ is fundamentally different from those put forward previously.

Highlights:

- Hydrothermal and sedimentary sources of light $\delta 66 \mathrm{Zn}>\delta 66 \mathrm{Zn}$ and abundance ratios to the major nutrients deconvolve key processes - Light $\delta 66 \mathrm{Zn}$ in the surface North Atlantic due to $\mathrm{Zn}$ addition, not scavenging

Keywords : zinc isotopes, North Atlantic, zinc sources, GEOTRACES, GEOVIDE 


\section{Introduction}

47 Zinc $(\mathrm{Zn})$ is an essential micronutrient for marine primary producers (Morel and Price, 2003). It is required for key metalloenzymes such as carbonic anhydrase, which is involved in carbon fixation, or alkaline phosphatase, which gives phytoplankton access to organic forms of phosphorus when phosphate concentrations are low (Sunda, 1989). As a result, the marine cycles of zinc and carbon are intrinsically linked.

52

53

Analytical advances over the last decade have enabled study of the stable isotope composition of $\mathrm{Zn}\left(\delta^{66} \mathrm{Zn}=\right.$ variations in ${ }^{66} \mathrm{Zn} /{ }^{64} \mathrm{Zn}$ expressed in parts per thousand deviation from the JMC Lyon standard), to investigate the processes controlling the marine Zn distribution (Bermin et al., 2006; Conway et al., 2013; Takano et al., 2013). In addition, the recent international programme GEOTRACES has provided a large quantity of high-quality data, from full-depth profiles and sections, allowing new insights into the large-scale distribution of trace elements, including $\mathrm{Zn}$ (Conway and John, 2014, 2015; Zhao et al., 2014; Vance et al., 2016; John et al., 2018; Weber et al., 2018; Wang et al., 2019). However, gaps remain in our understanding of the modern $\mathrm{Zn}$ cycle. Firstly, the $\delta^{66} \mathrm{Zn}$ of seawater (averaging $+0.46 \%$ ) is higher than the known inputs and lower than most known outputs, pointing to a missing budget term if the oceanic Zn cycle is in steady state (Little et al., 2014; Moynier et al., 2017). Secondly, north of the Southern Ocean, a shift toward light $\mathrm{Zn}$ isotope signatures in the dissolved pool is observed within the upper ocean $(<1000 \mathrm{~m})$. This is surprising, given that isotopic fractionation between phytoplankton cells and the dissolved pool is thought to be close to zero, or slightly in favour of light isotope uptake, which should leave the residual dissolved pool slightly heavy (John et al., 2007; Peel et al., 2009; Samanta et al., 2017; Köbberich and Vance, 2019; Wang et al., 2019). Laboratory experiments have suggested that $Z n$ released from degrading phytoplankton cells can 
71 be rapidly scavenged back onto organic matter, and that this adsorbed $\mathrm{Zn}$ is 72 isotopically heavier than the dissolved pool (John and Conway, 2014). Scavenging of 73 isotopically heavy $\mathrm{Zn}$ onto sinking biogenic particles has thus been suggested to 74 explain the low $\delta^{66} \mathrm{Zn}$ values in the upper ocean (Conway and John, 2014, 2015; John et al., 2018; Weber et al., 2018), although it should be noted that a dominant proportion of marine dissolved $\mathrm{Zn}$ is complexed to natural organic ligands (e.g. Ellwood and Van den Berg, 2000) and thus presumably not available for adsorption to particles.

Here we examine $\mathrm{Zn}$ isotopes and concentrations along a GEOTRACES section that crosses the North Atlantic from the Iberian Peninsula to Newfoundland (Fig. 1). The North Atlantic is a promising area to study biological, physical and geochemical processes affecting micronutrient distributions, as it is characterised by a strong spring bloom (Longhurst, 2010), the formation of globally-important deep water masses (e.g. Daniault et al., 2016), and a variety of trace metal sources (Ohnemus and Lam, 2014).

84 In this study, we focus our discussion on the processes responsible for the light isotope composition of Zn observed at the Reykjanes Ridge, at the sediment-water interface, and in the upper $500 \mathrm{~m}$ of the ocean. In doing so, we expand our analysis to data from the entire North Atlantic. We combine macronutrient/Zn ratios with $\mathrm{Zn}$ stable isotope data for the dissolved pool in order to better identify the processes that modify preformed Southern Ocean signatures in the low-latitude oceans. In contrast to previous studies that invoke scavenging removal of heavy $\mathrm{Zn}$ isotopes for the origin of light upper-ocean Zn (e.g. John and Conway, 2014), we conclude that the Zn isotope signature of the upper ocean is dominated by the addition of isotopically light $\mathrm{Zn}$ to upper-ocean water masses, whose preformed $\mathrm{Zn}$ concentrations are extremely low

94 (Vance et al., 2017; de Souza et al., 2018; Middag et al., 2019), and which are thus very sensitive to the addition of small amounts of $\mathrm{Zn}$. 


\section{Methods}

2.1. Study area and sample collection

Samples were collected during the GEOVIDE cruise (GEOTRACES GA01) from 15 May to 30 June 2014 (R/V Pourquoi Pas?). At six stations, 17 depths between the surface and the seafloor were sampled for dissolved $\mathrm{Zn}$ concentrations and stable isotope composition (expressed as $\delta^{66} \mathrm{Zn}$; see Eq. 1 below). These 6 stations (Fig. 1) are located within the Iberian basin (Station 13), the west European basin (Station 21), the Icelandic basin (Stations 32 and 38) with Station 38 just above the Reykjanes Ridge, the Irminger basin (Station 44) and the Labrador basin (Station 69).

Samples were collected using a clean rosette equipped with cleaned 12 litre GO-FLO bottles, following the recommendations of the GEOTRACES cookbook (Cutter et al., 2017). After recovery, the bottles were transferred into a clean container and seawater samples were filtered through $0.45 \mu \mathrm{m}$ polyethersulfone filters (Pall, Supor ${ }^{\mathrm{TM}}$ ) mounted in Swinnex polypropylene filter holders (Millipore). Between 1 and 4 litres of filtrate were collected into acid-cleaned polyethylene bottles. More details of the sampling procedure can be found in Gourain et al. (2019).

\subsection{Sample processing and analysis}

114 At ETH Zürich, samples were acidified to $\mathrm{pH} \sim 2$ by addition of concentrated hydrochloric acid $(\mathrm{HCl}$; Merck AnalaR grade, further purified by double sub-boiling 116 distillation) and left for at least 1 month before processing. All samples were processed 117 under clean laboratory conditions in clean hoods, using only trace metal clean Savillex 118 PFA labware. All water used was ultrapure $(\geq 18.2 \mathrm{M} \Omega . \mathrm{cm})$ and all acids and reagents were Merck AnalaR grade, further purified by single or double sub-boiling distillation. 
120 Samples were first doped with a ${ }^{67} \mathrm{Zn}-{ }^{64} \mathrm{Zn}$ double spike to achieve a sample:spike 121 ratio of $\sim 1$. After 48 hours of equilibration, an ammonium acetate buffer solution was 122 added and $\mathrm{pH}$ was increased to $5.0 \pm 0.3$. Zinc was extracted from seawater with 123 Nobias PA1 resin and purified using AGMP-1 anion exchange resin (Bermin et al., 124 2006; Takano et al., 2013; Vance et al., 2016). Total procedural blanks were assessed 125 by processing ultrapure water as a sample, and were $1.8 \pm 0.6 \mathrm{ng}$, with a $\delta^{66} \mathrm{Zn}$ of $+0.46 \pm 0.28 \%$ o (average and $2 S D, n=8$ ). Blank contributions were barely significant (mostly involving a correction of $0.01-0.02 \%$ ) for all except three samples: Station 1315m (0.10 \%o shift), Station 21-50m (0.08 \% shift) and Station 44-159m, (0.12\%o shift). Nonetheless, Table S1 gives blank-corrected data with propagated uncertainty in the blank amount and isotope composition. Isotopic analyses were performed at ETH Zürich using a Thermo-Finnigan Neptune

132 Plus multi-collector inductively-coupled-plasma mass spectrometer (MC-ICPMS) in 133 'low-resolution' mode. Samples were introduced in $1 \mathrm{~mL} 0.3 \mathrm{M}$ nitric acid $\left(\mathrm{HNO}_{3}\right)$ via a 134 CPI PFA nebulizer (50 $\mu$ L.min $\left.{ }^{-1}\right)$ attached to an Aridus II desolvating system. Dissolved $135 \mathrm{Zn}$ concentrations were obtained by isotope dilution. Analytical mass bias correction was performed using the double spike technique (Bermin et al., 2006). Dissolved Zn isotope compositions $\left(\delta^{66} \mathrm{Zn}\right)$ were calculated following the iterative approach of 138 Siebert et al. (2001) and are given in the standard delta per mil notation relative to the 139 JMC-Lyon standard:

$$
\delta^{66} Z n(\%)=\left[\frac{\left(\frac{6{ }^{66} Z n}{{ }^{64} Z n}\right)_{\text {sample }}}{\left(\frac{{ }^{66} Z n}{{ }^{64} Z n}\right)_{\text {JMC Lyon }}}-1\right] \times 1000
$$

142 During the course of this study, and owing to the exhaustion of the existing JMC-Lyon 143 stock, Zn data were normalised to a new primary standard, AA-ETH Zn. Where this 
144 was the case, data were converted to the JMC-Lyon delta scale by applying a 145 conversion factor of $-0.28 \%$ (Archer et al., 2017). Long-term reproducibility of $\mathrm{Zn}$

146 isotope analysis on the instrument is monitored by repeat analysis of a secondary 147 standard, IRMM-3702, which yields $\delta^{66} \mathrm{Zn}=+0.30 \pm 0.06 \%$, relative to JMC-Lyon, 148 over 5 years $(n=543,2 S D)$. Internal errors obtained from the mass spectrometry 149 analysis, propagated through the double spike calculations and including the 150 uncertainty arising from the blank correction, were generally lower than the long-term reproducibility. These internal uncertainties are given in the data table. Uncertainties

152 plotted on the figures are the internal uncertainties or the long-term reproducibility, 153 whichever is the larger. Zinc isotope reproducibility for samples, as assessed by full 154 analytical replicates of 14 samples, was consistent with long-term standard 155 reproducibility. Differences between these replicates ranged between 0.00 and 0.14 $\%$ and averaged $0.05 \pm 0.04 \%$. This laboratory has demonstrated agreement for $\mathrm{Zn}$ concentrations and isotopes with the GEOTRACES standards SAFe D1 and D2 using

158 similar methods in a number of past papers (Zhao et al., 2014; Sieber et al., 2020) and 159 with the GEOTRACES intermediate data product (IDP 2017; Schlitzer et al., 2018). 160 Furthermore, analyses of deep ocean samples yield the same results as obtained in other studies (e.g. Conway and John, 2014; Sieber et al., 2020; Vance et al., 2016;

162 Wang et al., 2019).

\subsection{Other oceanographic parameters}

164 Concentrations of the macronutrients silicate $(\mathrm{Si})$ and nitrate $\left(\mathrm{NO}_{3}{ }^{-}\right)$were obtained by the nutrient group at the LEMAR laboratory, using the method described in Aminot and Kérouel (2007). Because of technical problems, phosphate data are not available.

167 Hydrographic parameters (oxygen, salinity, temperature) were used to define the 
168

169

170

171

172

173

174

175

176

177

178

179

180

181

182

183

184

185

186

187

188

189

190

water mass distribution and the general circulation along the GEOVIDE transect, as described by García-lbáñez et al. (2018).

\subsection{Dissolved $\mathrm{Zn}^{*}$}

Since the first reliable $\mathrm{Zn}$ data (Bruland, 1980), and further confirmed by the efforts of the GEOTRACES programme to produce high-resolution Zn data (Schlitzer et al., 2018), a strong correlation is observed between $\mathrm{Zn}$ and Si concentrations throughout the global ocean (Vance et al., 2017; de Souza et al., 2018). Any variability in this relationship highlights either sources or sinks of $\mathrm{Zn}$ relative to $\mathrm{Si}$, such as biological uptake or regeneration of $\mathrm{Zn}$ and $\mathrm{Si}$ at different rates, or an addition to or loss from the water column (Wyatt et al., 2014; Roshan and Wu, 2015; Kim et al., 2017). To illustrate deviations from the global marine $\mathrm{Zn}$-Si correlation, we use the $\mathrm{Zn}^{*}$ parameter, which is defined as:

$$
Z n^{*}=[Z n]_{\text {measured }}-\left(Z n / S i_{\text {deep }} \times[S i]_{\text {measured }}\right)
$$

with $\mathrm{Zn} /$ Sideep set at $0.06 \mathrm{mmol} . \mathrm{mol}^{-1}$, representing the average $\mathrm{Zn} / \mathrm{Si}$ ratios in the global deep ocean. Note that the average $\mathrm{Zn} / \mathrm{Si}$ ratios across the GEOVIDE transect for depths $\geq 3000 m$ (excluding the deepest samples, closest to the sediment-water interface, in each depth profile; see section 4.2) is $0.08 \mathrm{mmol}^{\mathrm{mol}}{ }^{-1}$.

\section{Results}

Dissolved $\mathrm{Zn}$ concentrations vary from 0.07 to $5.95 \mathrm{nmol} . \mathrm{L}^{-1}, \delta^{66} \mathrm{Zn}$ values from -0.22 to $+0.53 \%$, and $\mathrm{Zn}^{*}$ from -0.25 to +5.29 nmol.L ${ }^{-1}$ across the entire GEOVIDE section (Fig. 2 and 3; Table S1). Dissolved Zn concentrations exhibit a typical nutrient-type profile, with low concentrations throughout the surface ocean $\left(<0.50 \mathrm{nmol} . \mathrm{L}^{-1}\right.$ in the 
191 upper $20 \mathrm{~m}$, except at Station 32 where it reaches $1.00 \mathrm{nmol} . \mathrm{L}^{-1}$ at $30 \mathrm{~m}$ ) and an

192 increase with depth, reaching up to $5.95 \mathrm{nmol} . \mathrm{L}^{-1}$ close to the Reykjanes Ridge.

$193 Z^{*}$ values in the upper ocean are close to zero, even if slightly positive $(+0.08 \pm 0.30$ 194 nmol. $L^{-1}, \mathrm{n}=9$, median $\pm 1 S D$ ), and increase with depth, reaching maximum values 195 close to the sea floor. The picture in the deep eastern part of the section (Iberian and 196 west European basins) is slightly more complex, with a mid-depth maximum in $\mathrm{Zn}^{*}$ 197 values overlying lower values between 2000 and $5000 \mathrm{~m}$. Overall, $\mathrm{Zn}^{*}$ values are 198 positive, indicating an enrichment of $\mathrm{Zn}$ relative to $\mathrm{Si}$. This general $\mathrm{Zn}$ enrichment is 199 also indicated by the greater $\mathrm{Zn} / \mathrm{Si}_{\text {deep }}$ ratio of the North Atlantic along GEOVIDE $200\left(0.08 \pm 0.03 \mathrm{mmol} . \mathrm{mol}^{-1}\right)$ compared to the world ocean $\left(0.06 \pm 0.02 \mathrm{mmol} . \mathrm{mol}^{-1} ;\right.$ Schlitzer 201 et al., 2018).

202 The deep ocean $(>1500 \mathrm{~m})$ across the GEOVIDE transect averages $+0.38 \pm 0.07 \%$ 203 (average $\pm 1 S D, n=27$ ) in $\delta^{66} \mathrm{Zn}$, which is nominally lighter than, but within error of, the 204 global average deep ocean $\delta^{66} \mathrm{Zn}$ value $(+0.46 \pm 0.13 \%$; $2 \mathrm{SD}, \mathrm{n}=312,2 \mathrm{SE}=0.01$ $205 \%$; Schlitzer et al., 2018). Apart from this, three zones stand out from the rest of the 206 section: the upper ocean (between the surface and $\sim 1000 \mathrm{~m}$ ), the area close to the 207 Reykjanes Ridge, and the sediment-water interface (Fig. 2). All are characterised by 208 light $Z n$ signatures, with median $\delta^{66} \mathrm{Zn}$ values of $-0.13 \pm 0.07 \%$ for the upper ocean $209(n=8),-0.01 \pm 0.07 \%$ around the Reykjanes Ridge $(n=4)$, and $+0.12 \pm 0.16 \%$ for the 210 sediment-water interface $(n=5)$, but they are associated with either high $\mathrm{Zn}$ 211 concentrations (close to the Reykjanes Ridge and the bottom) or low $\mathrm{Zn}$ 212 concentrations (upper ocean). 


\section{4. Discussion}

215 Apart from the marked maximum extending eastwards from the Reykjanes Ridge, the 216 distribution of $\mathrm{Zn}$ (Fig. 2) along the GEOVIDE transect bears a strong resemblance to 217 those of the major nutrients (cf. García-lbáñez et al., 2018), and especially that of Si, 218 reflected by the close correlation between their concentrations that is typical for the 219 open ocean (Fig. 4; Bruland, 1980; Vance et al., 2017; de Souza et al., 2018; Weber 220 et al., 2018). To first order, the cross-basin distributions of $\mathrm{Zn}$, Si and other 221 macronutrients are largely governed by the properties of the water masses found 222 along the transect: water masses formed in the North Atlantic and Nordic Seas are 223 macronutrient- and Zn-poor, and fill the basins west of the Reykjanes Ridge as well as the mid-depths across the entire transect, whereas macronutrient- and $\mathrm{Zn}$-rich waters of southern origin fill the abyss east of the ridge, below about $3000 \mathrm{~m}$ (e.g. GarcíaIbañez et al., 2018). However, despite this first-order water mass control on the elemental distributions of $\mathrm{Zn}$ and $\mathrm{Si}$, and in marked contrast to the silicon stable isotope distribution along GEOVIDE (Sutton et al., 2018), the $\delta^{66} \mathrm{Zn}$ distribution (Fig. 2) displays little systematic cross-basin variation. What stands out instead are the low $\delta^{66} \mathrm{Zn}$ values at mid-depths, near the bottom, and in the upper ocean. In the following, we discuss each of these in turn.

\subsection{Light $\mathrm{Zn}$ isotope signatures in the vicinity of the} Reykjanes Ridge

235 Elevated $Z n$ concentrations (5.95 nmol.L ${ }^{-1}$ ), high $\mathrm{Zn}^{*}$ (up to $+5 \mathrm{nmol} . \mathrm{L}^{-1}$ ) and light $\delta^{66} \mathrm{Zn}$ values $(-0.22 \%$ ) were determined at Station 38, just above the Reykjanes Ridge (Figs. 
$238 \mathrm{Zn}$ concentrations $\left(>2.40 \mathrm{nmol} . \mathrm{L}^{-1}\right)$, again associated with high $\mathrm{Zn}^{*}\left(>+1.7 \mathrm{nmol} . \mathrm{L}^{-1}\right)$ and light $\delta^{66} \mathrm{Zn}$ values (<+0.02\%), were also observed between 1500 and $2000 \mathrm{~m}$

240 within the Icelandic and west European basins to the east of the ridge (Stations 32 241 and 21, respectively). Data across this mid-depth $\mathrm{Zn}$ maximum from all three stations 242 exhibit a strong positive correlation between $\delta^{66} \mathrm{Zn}$ and 1/[Zn] (Fig. 5a), suggesting 243 that the "plume" of elevated Zn above and to the east of the Reykjanes Ridge can be explained by mixing between two components: ambient deep seawater and a 245 hydrothermal source. Indeed, hydrothermal vents along the Reykjanes Ridge have been shown to act as a source of other dissolved trace elements, such as iron and 247 manganese (Achterberg et al., 2018). Although their origin could not be definitively 248 determined, it has also been suggested that the enrichments in particulate and 249 dissolved iron and aluminium concentrations observed above Reykjanes Ridge during GEOVIDE (Gourain et al., 2019; Tonnard et al., 2020), as well as the elevated radium226 activity seen there (Le Roy et al., 2018), may also reflect the influence of 252 hydrothermal activity.

253 To assess the $\delta^{66} \mathrm{Zn}$ value of the hydrothermal end-member, we compare $\mathrm{Zn}$ 254 concentrations and isotopes observed within the hydrothermal plume at Station 38 with those of background deep seawater from surrounding stations (Station 32: 9901235m and 2463-3177m; Station 44: 1087-2851m; $[\mathrm{Zn}]_{\text {background }}=1.46 \pm 0.22 \mathrm{nmol} . \mathrm{L}^{-}$ 1 and $\delta^{66} \mathrm{Zn}_{\text {background }}=+0.42 \pm 0.06 \%$; median values; $\mathrm{n}=12$ ). The quantity of hydrothermally-sourced $\mathrm{Zn}$ at any depth is estimated by subtracting this background concentration from the measured concentration at this depth. The strong linear correlation between $\delta^{66} \mathrm{Zn}$ and the fraction of hydrothermally-derived $\mathrm{Zn}$ (calculated 261 by dividing the estimated quantity of hydrothermal $\mathrm{Zn}$ by the total $\mathrm{Zn}$ concentration) 262 suggests that the hydrothermal end-member bears a $\delta^{66} \mathrm{Zn}$ value of $-0.42 \pm 0.11 \%$ o 
263 (Fig. 5b). This value is very similar to the hydrothermal $\delta^{66} \mathrm{Zn}$ signature of $-0.5 \%$ estimated for the TAG hydrothermal field at $26^{\circ} \mathrm{N}$ in the North Atlantic (Conway and John, 2014). The total range of $\delta^{66} \mathrm{Zn}$ in pure hydrothermal fluids, from 0.00 to +1.33 $\%$ (John et al., 2008), with recent inferred values of $+0.24 \%$ at the East Pacific Rise

267 (John et al., 2018), suggest that the hydrothermal $\delta^{66} \mathrm{Zn}$ signature likely depends on 268 the ridge characteristics.

269 The low $\delta^{66} \mathrm{Zn}$ observed at Stations 32 and 21 is likely the result of transport by 270 Labrador Sea Water (LSW; Fig. 1), which crosses the Mid-Atlantic Ridge (MAR) at 271 latitudes around $50^{\circ} \mathrm{N}$ and spreads eastward into the Icelandic and west European 272 basins (e.g. Paillet et al., 1998; Sutton et al., 2018). The hydrothermal signal, acquired 273 when crossing the MAR, thus seems to propagate over a distance of $1000 \mathrm{~km}$ (from 274 the MAR to Station 21). This is in contrast to the observations of Conway and John 275 (2014) who did not find any extension of the Zn hydrothermal signal away from the 276 MAR along their east-west section, likely because of the north-south deep water mass 277 circulation there (Jenkins et al., 2015). Our results are, however, similar to other 278 studies that have reported long-distance transport of hydrothermally-derived $\mathrm{Zn}$ along 279 with the deep water mass flow direction (Wheat et al., 2002; Roshan et al., 2016; John 280 et al., 2018). The light hydrothermal $\delta^{66} \mathrm{Zn}$ signature may be transported as 281 nanoparticulate sulphide species (Conway and John, 2014; John et al., 2018), since 282 sulphide is known to preferentially sequester light Zn (Archer et al., 2004; Fujii et al., 283 2011; Vance et al., 2016). 

interface

287 A striking feature all across the transect is the sharp increase in $\mathrm{Zn}$ concentrations and 288 $\mathrm{Zn}^{*}$ at the very bottom of each profile (up to $4.02 \mathrm{nmol} \cdot \mathrm{L}^{-1}$ and $+2.5 \mathrm{nmol} . \mathrm{L}^{-1}$, 289 respectively; Fig. 3), associated with a shift to lighter $\delta^{66} \mathrm{Zn}$ signatures (as low as -0.16 $290 \%$ \%). Importantly, this shift consistently occurs between the deepest sample and the 291 one immediately above it, i.e. over a depth interval of 25 to $425 \mathrm{~m}$. The mirror image 292 between $\delta^{66} \mathrm{Zn}$ and $\mathrm{Zn}^{*}$ profiles suggests the addition of isotopically light $\mathrm{Zn}$ to 293 seawater close to the seafloor.

294 The fact that we observe isotopically-light sedimentary $\mathrm{Zn}$ input all across the transect 295 is surprising compared to the findings of previous studies, in which such isotopic 296 signals were observed only near margin sediments in the subtropical North Atlantic 297 (from -0.7 to $-0.5 \%$; Conway and John, 2014) and the California basin $(-0.3 \%$; 298 Conway and John, 2015). Since all our near-bottom samples were taken from the 299 same GO-FLO bottle (in rosette position 1), we must consider the possibility of 300 contamination. Zurbrick et al. (2018) observed a decrease of the excess lead (Pb) 301 concentration in this bottle (i.e. the difference in $\mathrm{Pb}$ concentrations between the nearbottom sample and its nearest neighbour) as the GEOVIDE cruise proceeded, pointing to a wash-out of $\mathrm{Pb}$ contamination from the GO-FLO bottle with time. However, we 304 observe no decrease of excess $\mathrm{Zn}$ over time (Fig. S1). Furthermore, unlike $\mathrm{Zn}, \mathrm{Pb}$ 305 concentrations are very low in the deep North Atlantic due to its different geochemical 306

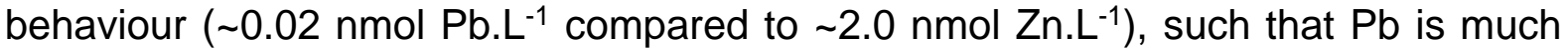
307 more prone to contamination in deep-water samples than $\mathrm{Zn}$. Therefore, we suggest 308 that these near-bottom samples reflect true ocean $\mathrm{Zn}$ signals that document a 309 sedimentary source of $\mathrm{Zn}$. 
310 On the GEOVIDE cruise, the deepest sample was taken at 4-32m (15m on average)

311 above the seafloor. This is in contrast to the subtropical North Atlantic section, along

312 which the light signal at the bottom was only found at the continental margins, where

313 the deepest samples came from between 33 and $299 \mathrm{~m}$ above the seafloor $(76 \mathrm{~m}$ on

314 average; Conway and John, 2014). This greater difference from the seafloor could

315 explain why the sedimentary input was not observed across the entire transect by

316 Conway and John (2014), and would suggest that the light sediment-derived $\delta^{66} \mathrm{Zn}$

317 signal does not persist far from the seafloor.

318 By comparing the deepest $\mathrm{Zn}$ concentration and $\delta^{66} \mathrm{Zn}$ value with those of the deep 319 seawater background at each station, the $\delta^{66} \mathrm{Zn}$ value of the local sedimentary source 320 (Table S2) can be deduced from mass balance. This calculation results in different sedimentary $\mathrm{Zn}$ isotope signatures for the eastern (Iberian and west European basins) and western (Icelandic, Irminger and Labrador basins) sections of the transect, with $\delta^{66} \mathrm{Zn}$ values of $0.01 \pm 0.02 \%$ and $-0.51 \pm 0.04 \%$ respectively (Table S2). This variation might be explained by different types of sediment, or different processes releasing $\mathrm{Zn}$ to seawater, on either side of the sub-arctic front (SAF; Fig. 1).

The processes that might provide light $\mathrm{Zn}$ to the bottom waters are not constrained by our data. However, upward diffusion from $\mathrm{Zn}$-rich pore waters is consistent with ${ }^{226} \mathrm{Ra}$ enrichments close to the seafloor (Le Roy et al., 2018) in the eastern basin. In the western basin, dissolution of sedimentary particles might be the important process controlling the $\mathrm{Zn}$ source, as Gourain et al. (2019) observed high particulate iron, manganese and aluminium concentrations associated with low beam transmissometry 332 values, suggesting sediment resuspension. Release of biogenic $\mathrm{Zn}$ from the 333 sediments or dissolution of $\mathrm{Zn}$ sulphides could also explain the near-bottom 334 isotopically light Zn signatures (Conway and John, 2014, 2015). Regardless of the 
precise process of addition, the extension of this near-bottom feature all the way across the GEOVIDE transect suggests that the addition of isotopically-light zinc from sediments is a much more pervasive process in the ocean than previously thought.

\subsection{Light $\mathrm{Zn}$ isotope signatures in the upper ocean}

340 Within the upper $500 \mathrm{~m}$, low $\mathrm{Zn}$ concentrations are observed in our North Atlantic 341 transect (as low as $0.07 \mathrm{nmol}^{-\mathrm{L}^{-1}}$; Fig. 2 and 3) as well as other oceanic regions north 342 of the Southern Ocean (Conway and John, 2014, 2015; John et al., 2018). Zn* values 343 in the GEOVIDE data are close to zero as a result of low $\mathrm{Zn}$ and Si concentrations, 344 though 13 out of 14 data points are positive (between -0.21 and +0.87 nmol.L-1; Fig. 3453 ), and $\delta^{66} \mathrm{Zn}$ values are low (as low as $-0.18 \%$ ). Other studies, in the North Atlantic 346 as well as in the tropical and North Pacific, have noted similarly low $\delta^{66} \mathrm{Zn}$ values in 347 the upper ocean (Conway and John, 2014, 2015; John et al., 2018; Vance et al., 2019; 348 Liao et al., 2020), which is at odds with the first-order expectation that biological $\mathrm{Zn}$ 349 uptake should slightly enrich upper-ocean $\mathrm{Zn}$ in its heavy isotopes, given the 350 fractionation observed in culture and deduced for natural freshwater systems (John et 351 al., 2007; Peel et al., 2009; Samanta et al., 2018; Köbberich and Vance, 2019). This 352 finding has led to the hypothesis that isotopically heavy $\mathrm{Zn}$ is removed by scavenging, explaining the light $\delta^{66} \mathrm{Zn}$ values in the upper ocean (Conway and John, 2014, 2015;

354 John et al., 2018; Weber et al., 2018). However, given the strong preformed upper355 ocean gradients in $\mathrm{Zn}$ concentrations resulting from interactions between biological 356 activity and physical circulation at the large scale, which primarily occur in the 357 Southern Ocean (e.g. Vance et al., 2017), assessing the presence of a small in-situ upper-ocean source or sink in the lower latitudes is a significant challenge. 
In order to disentangle the signal of local/regional upper-ocean processes from largescale nutrient cycling, we compare $\delta^{66} \mathrm{Zn}$ values and macronutrient/Zn ratios observed across the GEOVIDE section with data from the Southern Ocean (Fig. 6; we use macronutrient/Zn ratios, and not $\mathrm{Zn} /$ macronutrient ratios, since binary mixing produces 363 linear relationships between $\delta^{66} \mathrm{Zn}$ and $1 / \mathrm{Zn}$ ). The GEOVIDE isotope profiles, in 364 common with all others north of the Southern Ocean, contrast strongly with the 365 homogeneous isotope profiles observed south of the Antarctic Polar Front (Zhao et 366 al., 2014; Wang et al., 2019; Sieber et al., 2020). Water masses that fill the global ocean transport this homogeneous Southern Ocean $\delta^{66} \mathrm{Zn}$ signature northwards, whilst also influencing global distributions of $\mathrm{Zn}$ and the macronutrients nitrate $\left(\mathrm{NO}_{3}{ }^{-}\right)$ and Si (Sarmiento et al., 2004; Vance et al., 2017). Southern Ocean waters supplying the upper ocean are stripped of $\mathrm{Zn}$ relative to $\mathrm{NO}_{3}{ }^{-}$and phosphate, and thus bear high $\mathrm{NO}_{3} / \mathrm{Zn}$ ratios, whilst abyssal waters carry the equivalent regenerated $\mathrm{Zn}$, and thus bear $\mathrm{NO}_{3}-\mathrm{Zn}$ ratios 1-2 orders of magnitude lower. Ratios of $\mathrm{Si} / \mathrm{Zn}$ in the Southern

373 Ocean source waters vary much less than $\mathrm{NO}_{3} / \mathrm{Zn}$, by less than factor 2 , due to 374 coupled uptake of $\mathrm{Zn}$ and $\mathrm{Si}$ at the surface by Southern Ocean diatoms (Vance et al., 375 2017; de Souza et al., 2018). These Southern Ocean water masses are transported 376 northwards globally, including into the northern North Atlantic: abyssal water masses of Southern Ocean origin can be traced as far north as $58^{\circ} \mathrm{N}$ (e.g. van Aken and 378 Becker, 1996), whilst the upper limb of the meridional overturning circulation transports 379 upper Southern Ocean water masses into the North Atlantic (e.g. Marshall and Speer, 380 2012) where they influence the biogeochemical characteristics of water masses 381 formed in the North Atlantic and Nordic seas (e.g. (Williams et al., 2006; de Souza et 382 al., 2012, 2015). The isotopic and elemental ratio signatures of Southern Ocean water 383 masses (black rectangles in Fig. 6; Sieber et al., 2020) thus provide the framework 
within which we interpret the controls on $\mathrm{Zn}$ and its isotopes here: deviations from the

Southern Ocean elemental ratio signatures indicate a decoupling of $\mathrm{Zn}$ from the macronutrients, which may reflect either differential biogeochemical cycling (e.g. different depths of remineralisation) or the presence of sources or sinks of $\mathrm{Zn}$ that do not affect macronutrient concentrations.

As can be seen in Fig. 6, $\mathrm{NO}_{3}-\mathrm{Zn}$ and $\mathrm{Si} / \mathrm{Zn}$ in the deepest ocean across GEOVIDE 390 (i.e., in southern-sourced deep waters, depths $>3000 \mathrm{~m}$ east of the Reykjanes Ridge; empty symbols in Fig. 6) are generally near-identical to the signatures observed in deep Southern Ocean waters. In the intermediate and upper ocean, however, the GEOVIDE data show lower $\mathrm{NO}_{3} / \mathrm{Zn}$ and $\mathrm{Si} / \mathrm{Zn}$ ratios than the relevant Southern Ocean source, up to a factor of 260 and 11 respectively. This decoupling between $\mathrm{Zn}$ 395 and the macronutrients, with a decrease in macronutrient/Zn ratios, suggests that there is an addition, not removal, of $\mathrm{Zn}$ relative to $\mathrm{NO}_{3}{ }^{-}$and $\mathrm{Si}$, especially in the upper ocean. In the next section, we consider the influence of this relative $\mathrm{Zn}$ source on the $\delta^{66} \mathrm{Zn}$ distribution over the entire North Atlantic.

\subsection{Addition of isotopically light $\mathrm{Zn}$ : a pervasive process in} the North Atlantic

402 Isotopically light $\mathrm{Zn}$ signatures in the upper ocean have also been observed in the 403 subtropical North Atlantic ( $\delta^{66} \mathrm{Zn}$ as low as $-0.69 \%$ at $80 \mathrm{~m}$, GA03 transect; Conway 404 and John, 2014), as well as in other ocean basins (John et al., 2018). Here, we aim to 405 demonstrate that the low upper-ocean $\delta^{66} \mathrm{Zn}$ signature observed in the entire North 406 Atlantic (GA03 \& GEOVIDE sections; Schlitzer et al., 2018) has a single cause: the 407 addition of isotopically light $\mathrm{Zn}$. 
408 Figure 7 shows the relationship between $\mathrm{NO}_{3}^{-} / \mathrm{Zn}$ (Fig. 7a) or Si/Zn (Fig. 7b) and $\delta^{66} \mathrm{Zn}$

409 for all North Atlantic data. These North Atlantic data are compared to the 410 corresponding Southern Ocean signatures (black rectangles), which vary in elemental 411 ratios but not in $\delta^{66} \mathrm{Zn}$. Samples from oxygen-rich waters (oxygen saturation > 60\%; 412 colour coding in Fig. 7) generally follow trends towards lower $\delta^{66} \mathrm{Zn}$ values with 413 decreasing $\mathrm{NO}_{3}{ }^{-} / \mathrm{Zn}$ and $\mathrm{Si} / \mathrm{Zn}$ (black arrows). These trends illustrate the fact that light $414 \delta^{66} \mathrm{Zn}$ values are mostly associated with an enrichment in $\mathrm{Zn}$ relative to $\mathrm{Si}$ or $\mathrm{NO}_{3}^{-}$(i.e., 415 lower macronutrient/Zn ratios). This relationship suggests that the North Atlantic $\delta^{66} \mathrm{Zn}$ 416 distribution is influenced by the addition of isotopically light $\mathrm{Zn}$, similar to the recent 417 inference of an isotopically light external source influencing the $\delta^{66} \mathrm{Zn}$ distribution of 418 the Northwest Pacific (Liao et al., 2020). In Figure 7, Zn-poor upper-ocean samples, 419 which plot towards the bottom left corner of each plot, tend to be more strongly 420 affected, appearing to have both a stronger relative source (at lower macronutrient 421 and $\mathrm{Zn}$ concentrations) and lower $\delta^{66} \mathrm{Zn}$ values. Conversely, samples from oxygen422 poor regions (oxygen saturation < 50\%) such as at the Mauritanian upwelling regime 423 show an opposite trend, towards higher $\mathrm{NO}_{3}{ }^{-} / \mathrm{Zn}$ and $\mathrm{Si} / \mathrm{Zn}$ ratios than the Southern 424 Ocean. This depletion of $\mathrm{Zn}$ relative to the macronutrients was noted by Conway and 425 John (2014), who attributed it to $\mathrm{Zn}$ loss either through sulphide precipitation or 426 scavenging onto particles sinking through the oxygen-poor zone.

427 Figure 8 shows the correlation between Si and Zn concentrations in the North Atlantic, 428 with data points colour-coded for $\delta^{66} \mathrm{Zn}$ values. Vertical deviations from the well-known near-linear global Zn-Si relationship (Vance et al., 2017; de Souza et al., 2018; Roshan 430 et al., 2018; Weber et al., 2018) indicate either addition (data above the dotted line) or 431 removal (data below the dotted line) of $\mathrm{Zn}$ relative to Si. Even in this simple 432 representation, numerous sources of relative $\mathrm{Zn}$ addition are visible in the North 
433 Atlantic data. Hydrothermal and sedimentary addition of $\mathrm{Zn}$ relative to $\mathrm{Si}$ is seen for

434 the deep ocean (Si concentrations $\geq 10 \mu \mathrm{mol}^{\mathrm{L} \mathrm{L}^{-1}}$ ), with the associated $\delta^{66} \mathrm{Zn}$ being 435 variable but relatively low (between -0.2 and $+0.3 \%$ ). However, the cluster of data 436 points above the global relationship at low Si concentrations $\left(<5 \mu \mathrm{mol} . \mathrm{L}^{-1}\right)$ is a clear 437 sign of relative excess $\mathrm{Zn}$ in the Si-poor shallow ocean. Importantly, these samples 438 are characterised by the lowest $\delta^{66} \mathrm{Zn}$ values observed in the North Atlantic (between $439-0.6$ and $-0.1 \% 0)$.

440 Taken together, our analysis of the North Atlantic $\delta^{66} \mathrm{Zn}$ distribution in the large-scale 441 biogeochemical context suggests that addition of isotopically light $\mathrm{Zn}$ is the dominant 442 process controlling the upper-ocean $\mathrm{Zn}$ isotope signature, at least in the North Atlantic.

443 Macronutrient/Zn depth profiles (Fig. 6) and systematics (Fig. 7 and 8) suggest that 444 this addition may be pervasive over the upper $2000-3000 \mathrm{~m}$ of the water column; this 445 suggests that the addition is most clearly reflected in upper-ocean $\delta^{66} \mathrm{Zn}$ values mainly 446 because preformed $\mathrm{Zn}$ concentrations are extremely low there (Middag et al., 2019). 447 In these waters, $\mathrm{Zn}$ isotope compositions can be more easily modified by modest $\mathrm{Zn}$ 448 inputs compared to $\mathrm{Zn}$-rich deep waters, such that a broadly-distributed source of 449 isotopically light $\mathrm{Zn}$ addition would be more easily observed in the $\mathrm{Zn}$-poor upper 450 ocean.

\subsection{Potential sources of isotopically light $\mathrm{Zn}$}

453 It is clear from the preceding discussion that different sources contribute to the 454 isotopically light Zn observed throughout the GEOVIDE section. Hydrothermal inputs 455 and sedimentary sources (see Sections 4.1 and 4.2 respectively) have $\delta^{66} \mathrm{Zn}$ values 456 of around $-0.5 \%$. The most important new conclusion here is that the open upper 
ocean also sees the addition of light $\mathrm{Zn}$. We see two broad mechanisms for the origin

458 of this light Zn.

459 It is possible that the source responsible for the isotopically light $\mathrm{Zn}$ in the upper ocean 460 (see Sections 4.3 and 4.4), which bears a similar isotope signature to the hydrothermal 461 and sedimentary sources (Fig. 7), is the same as one of these, transported laterally, 462 and with a much more obvious impact on the open upper ocean because of the low 463 Zn concentrations there. Thus, for example, sedimentary sources of isotopically light $464 \mathrm{Zn}$ observed previously in bottom waters close to the Iberian, North and South 465 American margins (Conway and John, 2014, 2015; John et al., 2018), and here more 466 pervasively at the sediment-water interface, could be transported laterally into the 467 open upper ocean, where its influence may remain visible over greater spatial scales 468 than in the deep ocean due to lower background concentrations. Conway and John (2014) have pointed to the potential role of the Gulf Stream in transporting light surface

$470 \mathrm{Zn}$ isotope signatures from the North American coast into the basin. Similarly, currents 471 or water masses may have played a role in transporting the isotopically light $\mathrm{Zn}$ across 472 the GEOVIDE transect. For example, an isotopically light $\mathrm{Zn}$ signal could be 473 transported from the Caribbean and the American coasts across the North Atlantic, 474 via the North Atlantic Current (NAC; Fig. 1).

475 It is also possible that the light zinc in the upper ocean and close to the sediment-water 476 interface both have their ultimate origin in the upper ocean. For example, particulate 477 material from the atmosphere or from rivers transits the surface ocean on its way to 478 the sediment, potentially releasing labile $\mathrm{Zn}$ in the upper ocean and continuing to act 479 as a source from the seafloor over longer timescales. Zinc isotope signatures for rivers 480 and aeolian dust have been reported by Little et al. (2014) and average +0.33 and $481+0.37 \%$ respectively, values that are similar to the upper continental crust (UCC; 
$+0.31 \pm 0.12 \%$; Moynier et al., 2017). These sources are thus too heavy to explain

483 the isotopically light $\mathrm{Zn}$ signature. However, across the GEOVIDE transect, $\mathrm{Zn}$ in dust

484 is a mixture of mineral and anthropogenic sources (Shelley et al., 2017), and the 485 anthropogenic component is more important close to the European and American 486 continents (Shelley et al. 2018). Volatile contaminants (smelter dust, fly ash, 487 emissions) tend to have light $\mathrm{Zn}$ isotope signatures (from -0.67 to $+0.21 \%$; Mattielli et 488 al., 2009; Fekiacova et al., 2015), which are consistent with the light $\mathrm{Zn}$ values in the 489 upper $100 \mathrm{~m}$ (between -0.17 and $-0.01 \%$ ). It is also well known that these 490 anthropogenic components are much more labile than mineral dust (Conway et al., 2019; Desboeufs et al., 2005; Hsu et al., 2005; Shelley et al., 2018). Alternatively, the 492 Tagus river, which drains into the Atlantic ocean near Lisbon, is affected by agriculture and industrial activities; it is known to discharge large quantities of Zn (Le Gall et al., 494 1999; Cotté-Krief et al., 2000) but, to our knowledge, there are no $\mathrm{Zn}$ isotope data available. These riverine contaminants could be transmitted to estuarine sediments, and transported off the coast to transmit their isotope signatures to the dissolved pool after dissolution. In summary, there is at least the potential for both aeolian and riverine sources of anthropogenically-sourced light $\mathrm{Zn}$ to the ocean.

\section{Conclusion}

501 We have analysed $\mathrm{Zn}$ concentrations and stable isotope compositions in the North 502 Atlantic across the GEOVIDE section. The greatest variations in $\delta^{66} \mathrm{Zn}$, all associated 503 with isotopically light $\mathrm{Zn}$, are observed close to the Reykjanes Ridge, close to the 504 seafloor and in the upper ocean. Close to the Reykjanes Ridge, the hydrothermal vent releases isotopically light $\mathrm{Zn}$ to the ocean that is transported eastwards into the 506 northeast Atlantic. This hydrothermal Zn may not be truly dissolved, but rather 
associated with sulphide nanoparticles. We also show that the addition of isotopically

508 light $\mathrm{Zn}$ from the sediments is a much more pervasive process in the ocean than

509 previously recognised. Possibly due to higher depth resolution near the sediment-

510 water interface than previous studies, we observed this feature all across the transect,

511 rather than just at the margins. Finally, our analysis of the relationships between

512 macronutrient/Zn ratios and $\mathrm{Zn}$ isotopes strongly suggests that the isotopically light $\mathrm{Zn}$

513 signature of the upper ocean is also caused by an addition of $\mathrm{Zn}$ to the ocean.

514 Overall, we put forward a fundamentally different view of upper-ocean $\mathrm{Zn}$ and its 515 isotopes than that presented in previous studies, one whose framework for the 516 interpretation of oceanic $\mathrm{Zn}$ and its isotopes emphasises preformed Southern Ocean517 derived water mass signatures and how they are modified in the low-latitude oceans.

518 If correct, it is the addition of light $\mathrm{Zn}$ that explains the low $\delta^{66} \mathrm{Zn}$ values of the low-

519 latitude upper ocean, and not the removal of heavy isotopes. Though the precise 520 source of the light $\mathrm{Zn}$ added to the upper ocean remains an open question, it seems 521 possible that it could be anthropogenic in origin.

522

\section{Acknowledgements}

524 We would like to thank the captain, the crew and the co-chief scientist Pascale 525 Lherminier, for their great work and support during the GEOVIDE cruise. Special 526 thanks go to members of the trace metal clean sampling team including Julia Boutorh, 527 Marie Cheize, Leonardo Contreira, François Lacan, Jan-Lukas Menzel Barraqueta 528 and Rachel Shelley. We also would like to thank Fabien Perault, Emmanuel De Saint 529 Léger (CNRS DT-INSU) for their help during the CTD deployments; Catherine 530 Schmechtig for the GEOVIDE database management; Emilie Grossteffan, Manon Le 
531 Goff, Morgane Gallinari and Paul Tréguer (LEMAR, IUEM) for the analysis of nutrients.

532 The GEOVIDE project was supported by the French National Research Agency (ANR533 13-BS06-0014 and ANR-12-PDOC-0025-01), the French National Centre for Scientific 534 Research (CNRS-LEFE-CYBER), Ifremer and the "Laboratoire d'Excellence" Labex535 Mer (ANR-10-LABX-19). This work received financial support from the Swiss National 536 Science Foundation through grant 200020_165904. 
538

539

540

541

542

543

544

545

546

547

548

549

550

551

552

553

554

555

556

557

558

559

560

561

562

563

564

565

566

567

568

569

570

571

572

573

574

575

576

577

578

579

580

581

582

583

584

Achterberg, E.P., Steigenberger, S., Marsay, C.M., LeMoigne, F.A.C., Painter, S.C., Baker, A.R., Connelly, D.P., Moore, C.M., Tagliabue, A., Tanhua, T., 2018. Iron biogeochemistry in the high latitude North Atlantic Ocean. Sci. Rep. 8, 1-15. doi:10.1038/s41598-018-19472-1

Aminot, A., Kérouel, R., 2007. Dosage automatique des nutriments dans les eaux marines: méthodes en flux continu, Ifremer-Qu. ed.

Archer, C., Andersen, M.B., Cloquet, C., Conway, T.M., Dong, S., Ellwood, M., Moore, R., Nelson, J., Rehkämper, M., Rouxel, O., Samanta, M., Shin, K.C., Sohrin, Y., Takano, S., Wasylenki, L., 2017. Inter-calibration of a proposed new primary reference standard AA-ETH Zn for zinc isotopic analysis. J. Anal. At. Spectrom. 32, 415-419. doi:10.1039/c6ja00282j

Archer, C., Vance, D., Butler, I., 2004. Abiotic Zn isotope fractionations associated with ZnS precipitation. Geochim. Cosmochim. Acta 68, A325-A325. doi:10.1016/j.gca.2004.05.008

Bermin, J., Vance, D., Archer, C., Statham, P.J., 2006. The determination of the isotopic composition of $\mathrm{Cu}$ and $\mathrm{Zn}$ in seawater. Chem. Geol. 226, 280-297. doi:10.1016/j.chemgeo.2005.09.025

Bruland, K.W., 1980. Oceanographic distributions of cadmium, zinc, nickel, and copper in the North Pacific. Earth Planet. Sci. Lett. 47, 176-198. doi:10.1016/0012-821X(80)90035-7

Conway, T.M., Hamilton, D.S., Shelley, R.U., Aguilar-Islas, A.M., Landing, W.M., Mahowald, N.M., John, S.G., 2019. Tracing and constraining anthropogenic aerosol iron fluxes to the North Atlantic Ocean using iron isotopes. Nat. Commun. 10, 2628. doi:10.1038/s41467-019-10457-w

Conway, T.M., John, S.G., 2015. The cycling of iron, zinc and cadmium in the North East Pacific Ocean - Insights from stable isotopes. Geochim. Cosmochim. Acta 164, 262-283. doi:10.1016/j.gca.2015.05.023

Conway, T.M., John, S.G., 2014. The biogeochemical cycling of zinc and zinc isotopes in the North Atlantic Ocean. Global Biogeochem. Cycles 28, 11111128. doi:10.1002/2014GB004862.Received

Conway, T.M., Rosenberg, A.D., Adkins, J.F., John, S.G., 2013. A new method for precise determination of iron, zinc and cadmium stable isotope ratios in seawater by double-spike mass spectrometry. Anal. Chim. Acta 793, 44-52. doi:10.1016/j.aca.2013.07.025

Cotté-Krief, M.-H., Guieu, C., Thomas, A.J., Martin, J.-M., 2000. Sources of Cd, Cu, $\mathrm{Ni}$ and $\mathrm{Zn}$ in Portuguese coastal waters. Mar. Chem. 71, 199-214.

Cutter, G., Casciotti, K., Croot, P., Geibert, W., Heimbürger, L.-E., Lohan, M., Planquette, H., Van De Flierdt, T., 2017. Sampling and the sample-handling protocoles for GEOTRACES cruises.

doi:http://www.geotraces.org/science/intercalibration/222-sampling-and-samplehandling-protocols-for-geotraces-cruises

Daniault, N., Mercier, H., Lherminier, P., Sarafanov, A., Falina, A., Zunino, P., Pérez, F.F., Ríos, A.F., Ferron, B., Huck, T., Thierry, V., Gladyshev, S., 2016. The northern North Atlantic Ocean mean circulation in the early 21st century. Prog. Oceanogr. 146, 142-158. doi:10.1016/j.pocean.2016.06.007

de Souza, G.F., Khatiwala, S.P., Hain, M.P., Little, S.H., Vance, D., 2018. On the origin of the marine zinc-silicon correlation. Earth Planet. Sci. Lett. 492, 22-34. 
600

601

602

603

604

605

606

607

608

609

610

611

612

613

614

615

616

617

618

619

620

621

622

623

624

625

626

627

628

629

630

631

632

633

634 doi:10.1016/j.epsl.2018.03.050

de Souza, G.F., Reynolds, B.C., Rickli, J., Frank, M., Saito, M.A., Gerringa, L.J.A., Bourdon, B., 2012. Southern Ocean control of silicon stable isotope distribution in the deep Atlantic Ocean. Global Biogeochem. Cycles 26, 1-13. doi:10.1029/2011GB004141

de Souza, G.F., Slater, R.D., Hain, M.P., Brzezinski, M.A., Sarmiento, J.L., 2015. Distal and proximal controls on the silicon stable isotope signature of North Atlantic Deep Water. Earth Planet. Sci. Lett. 432, 342-353. doi:10.1016/j.epsl.2015.10.025

Desboeufs, K. V., Sofikitis, A., Losno, R., Colin, J.L., Ausset, P., 2005. Dissolution and solubility of trace metals from natural and anthropogenic aerosol particulate matter. Chemosphere 58, 195-203. doi:10.1016/j.chemosphere.2004.02.025

Ellwood, M.J., Van den Berg, C.M.G., 2000. Zinc speciation in the northeastern Atlantic ocean. Mar. Chem. 68, 295-306. doi:10.1016/S0304-4203(99)00085-7

Fekiacova, Z., Cornu, S., Pichat, S., 2015. Tracing contamination sources in soils with $\mathrm{Cu}$ and $\mathrm{Zn}$ isotopic ratios. Sci. Total Environ. 517, 96-105. doi:10.1016/j.scitotenv.2015.02.046

Fujii, T., Moynier, F., Pons, M.L., Albarède, F., 2011. The origin of Zn isotope fractionation in sulfides. Geochim. Cosmochim. Acta 75, 7632-7643. doi:10.1016/j.gca.2011.09.036

García-lbáñez, M.I., Pérez, F.F., Lherminier, P., Zunino, P., Mercier, H., Tréguer, P., 2018. Water mass distributions and transports for the 2014 GEOVIDE cruise in the North Atlantic. Biogeosciences 15, 2075-2090. doi:10.5194/bg-15-20752018

Gourain, A., Planquette, H., Cheize, M., Lemaitre, N., Menzel Barraqueta, J.L., Shelley, R., Lherminier, P., Planquette, H., 2019. Inputs and processes affecting the distribution of particulate iron in the North Atlantic along the GEOVIDE (GEOTRACES GA01) section. Biogeosciences 16, 1563-1582. doi:10.5194/bg16-1563-2019

Hsu, S.C., Lin, F.J., Jeng, W.L., 2005. Seawater solubility of natural and anthropogenic metals within ambient aerosols collected from Taiwan coastal sites. Atmos. Environ. 39, 3989-4001. doi:10.1016/j.atmosenv.2005.03.033

Jenkins, W.J., Smethie, W.M., Boyle, E.A., Cutter, G.A., 2015. Water mass analysis for the U.S. GEOTRACES (GA03) North Atlantic sections. Deep. Res. Part II Top. Stud. Oceanogr. 116, 6-20. doi:10.1016/j.dsr2.2014.11.018

John, S.G., Conway, T.M., 2014. A role for scavenging in the marine biogeochemical cycling of zinc and zinc isotopes. Earth Planet. Sci. Lett. 394, 159-167. doi:10.1016/j.epsl.2014.02.053

John, S.G., Geis, R.W., Saito, M.A., Boyle, E.A., 2007. Zinc isotope fractionation during high-affinity and low-affinity zinc transport by the marine diatom Thalassiosira oceanica. Limnol. Oceanogr. 52, 2710-2714. doi:10.4319/lo.2007.52.6.2710

John, S.G., Helgoe, J., Townsend, E., 2018. Biogeochemical cycling of Zn and Cd and their stable isotopes in the Eastern Tropical South Pacific. Mar. Chem. 201, 66-76. doi:10.1016/j.marchem.2017.06.003

John, S.G., Rouxel, O.J., Craddock, P.R., Engwall, A.M., Boyle, E.A., 2008. Zinc stable isotopes in seafloor hydrothermal vent fluids and chimneys. Earth Planet. Sci. Lett. 269, 17-28. doi:10.1016/j.epsl.2007.12.011

Kim, T., Obata, H., Nishioka, J., Gamo, T., 2017. Distribution of Dissolved Zinc in the Western and Central Subarctic North Pacific. Global Biogeochem. Cycles 31, 
Köbberich, M., Vance, D., 2019. Zn isotope fractionation during uptake into marine phytoplankton: Implications for oceanic zinc isotopes. Chem. Geol. doi:10.1016/j.chemgeo.2019.04.004

Le Gall, A.C., Statham, P.J., Morley, N.J., Hydes, D.J., Hunt, C.H., 1999. Processes influencing distributions and concentrations of $\mathrm{Cd}, \mathrm{Cu}, \mathrm{Mn}$ and $\mathrm{Ni}$ at the North West European shelf break. Mar. Chem. 68, 97-115.

Le Roy, E., Sanial, V., Charette, M.A., van Beek, P., Lacan, F., Jacquet, S.H.M., Henderson, P.B., Souhaut, M., García-Ibáñez, M.I., Jeandel, C., Pérez, F.F., Sarthou, G., 2018. The 226Ra-Ba relationship in the North Atlantic during GEOTRACES-GA01. Biogeosciences 15, 3027-3048. doi:10.5194/bg-15-30272018

Liao, W.H., Takano, S., Yang, S.C., Huang, K.F., Sohrin, Y., Ho, T.Y., 2020. Zn isotope composition in the water column of the northwestern Pacific ocean: the importance of external sources. Global Biogeochem. Cycles 34. doi:10.1029/2019GB006379

Little, S.H., Vance, D., Walker-Brown, C., Landing, W.M., 2014. The oceanic mass balance of copper and zinc isotopes, investigated by analysis of their inputs, and outputs to ferromanganese oxide sediments. Geochim. Cosmochim. Acta 125, 673-693. doi:10.1016/j.gca.2013.07.046

Longhurst, A.R., 2010. Ecological geography of the sea, Academic P. ed. San Diego.

Marshall, J., Speer, K., 2012. Closure of the meridional overturning circulation through Southern Ocean upwelling. Nat. Geosci. 5, 171-180. doi:10.1038/ngeo1391

Mattielli, N., Petit, J.C.J., Deboudt, K., Flament, P., Perdrix, E., Taillez, A., RimetzPlanchon, J., Weis, D., 2009. Zn isotope study of atmospheric emissions and dry depositions within a $5 \mathrm{~km}$ radius of a $\mathrm{Pb}-\mathrm{Zn}$ refinery. Atmos. Environ. 43, 1265-1272. doi:10.1016/j.atmosenv.2008.11.030

Middag, R., de Baar, H.J.W., Bruland, K.W., 2019. The relationships between dissolved zinc and major nutrients phosphate and silicate along the GEOTRACES GA02 transect in the west Atlantic Ocean. Global Biogeochem. Cycles 33, 63-84. doi:10.1029/2018GB006034

Morel, F.M.M., Price, N.M., 2003. The Biogeochemical Cycles of Trace Metals in the Oceans. Science (80-. ). 300, 944-947. doi:10.1126/science.1083545

Moynier, F., Vance, D., Fujii, T., Savage, P., 2017. The Isotope Geochemistry of Zinc and Copper. Rev. Mineral. Geochemistry 82, 543-600. doi:10.2138/rmg.2017.82.13

Ohnemus, D.C., Lam, P.J., 2014. Cycling of Lithogenic Marine Particulates in the US GEOTRACES North Atlantic Transect. Deep Sea Res. Part II Top. Stud. Oceanogr. 116, 283-302. doi:http://dx.doi.org/10.1016/j.dsr2.2014.11.019

Paillet, J., Arhan, M., McCartney, M.S., 1998. Spreading of Labrador Sea Water in the eastern North Atlantic. J. Geophys. Res. Ocean. 103, 10223-10239. doi:10.1029/98jc00262

Peel, K., Weiss, D., Sigg, L., 2009. Zinc isotope composition of settling particles as a proxy for biogeochemical processes in lakes: Insights from the eutrophic Lake Greifen, Switzerland. Limnol. Oceanogr. 54, 1699-1708. doi:10.4319/lo.2009.54.5.1699

Roshan, S., DeVries, T., Wu, J., Chen, G., 2018. The Internal Cycling of Zinc in the Ocean. Global Biogeochem. Cycles 32, 1833-1849. doi:10.1029/2018GB006045 
Roshan, S., Wu, J., 2015. Water mass mixing: The dominant control on the zinc distribution in the North Atlantic Ocean. Global Biogeochem. Cycles 29, 10601074. doi:10.1002/2014GB005026

Roshan, S., Wu, J., Jenkins, W.J., 2016. Long-range transport of hydrothermal dissolved Zn in the tropical South Pacific. Mar. Chem. 183, 25-32. doi:10.1016/j.marchem.2016.05.005

Samanta, M., Ellwood, M.J., Sinoir, M., Hassler, C.S., 2017. Dissolved zinc isotope cycling in the Tasman Sea, SW Pacific Ocean. Mar. Chem. 192, 1-12. doi:10.1016/j.marchem.2017.03.004

Samanta, M., Ellwood, M.J., Strzepek, R.F., 2018. Zinc isotope fractionation by Emiliania huxleyi cultured across a range of free zinc ion concentrations. Limnol. Oceanogr. 63, 660-671. doi:10.1002/Ino.10658

Sarmiento, J.L., Gruber, N., Brzezinski, M. a, Dunne, J.P., 2004. High-latitude controls of thermocline nutrients and low latitude biological productivity. Nature 427, 56-60. doi:10.1038/nature10605

Schlitzer, R., Anderson, R.F., Masferrer Dodas, E., Lohan, M.C., Geibert, W., Tagliabue, A., Bowie, A.R., Jeandel, C., Maldonado, M.T., Landing, W.M., Cockwell, D., Steinfeldt, R., Morton, P.L., Queroue, F., Hawco, N., Nishioka, J., Milne, A., Cossa, D., Pradoux, C., Schlitzer, R., Vivancos, S.M., Fleisher, M.Q., Bauch, D., Closset, I., van Aken, H.M., Daniels, C., Gerringa, L.J.A., Cullen, J.T., Goldstein, S.L., van de Flierdt, T., Church, T.M., Dumousseaud, C., Bouman, H., Hatta, M., Barraqueta, J.-L.M., Slater, E., Swift, J.H., Little, S., Wu, J., Till, R., van Heuven, S., Lherminier, P., Nakaguchi, Y., Agather, A., Remenyi, T., Rigaud, S., Owens, S., Lam, P.J., Cardinal, D., Wyatt, N., Chance, R., Carlson, C., Bates, N.R., Andersen, M., Jenkins, W.J., Sigman, D.M., Hartman, A., Kumamoto, Y., Kenna, T.C., Hathorne, E.C., Xie, R.C., Wuttig, K., Ziveri, P., Hayes, C.T., Butler, E., Salt, L.A., Tuerena, R., Croot, P., Dieu, H.T., Dodas, E.M., Casacuberta, N., Townsend, A.T., Heimbürger, L.-E., Velazquez, S., Laan, P., Robinson, L.F., Thomas, A., Heller, M., Gault-Ringold, M., van Weerlee, E., Till, C.P., Radic, A., Branellec, P., Ellwood, M., Rijkenberg, M.J.A., Lambelet, M., Isshiki, K., Speich, S., Garcia-Solsona, E., Rehkämper, M., Black, E., Kipp, L., Niedermiller, J., Stichel, T., Fröllje, H., Resing, J.A., Gonzalez, S.R., Alexandra Weigand, M., Lee, J.-M., Cai, P., Chaves, J.E., Dulaquais, G., Brissebrat, G., Villa-Alfageme, M., Warner, M.J., Shelley, R., Weinstein, Y., Moncoiffe, G., Cockwell, D., Abadie, C., Wu, Y., Ho, P., Stirling, C.H., Tagliabue, A., Echegoyen-Sanz, Y., Mieruch, S., Schlosser, C., Sonke, J.E., Measures, C., van der Merwe, P., Mcclain, C.R., Rosenberg, M., Gilbert, M., Lohan, M., Castrillejo, M., Duggan, B., Bruland, K.W., Noble, A., Woodward, E.M.S., Townsend, E., Labatut, M., Sarthou, G., Auro, M., Schnetger, B., Helgoe, J., Galer, S.J.G., Bakker, K., Jacquot, J.E., Boye, M., Kretschmer, S., Obata, H., Xiang, Y., Fahrbach, E., Christl, M., Fripiat, F., Russell Flegal, A., Janssen, D.J., Middag, R., Planquette, H., Zieringer, M., Huang, K.-F., Scher, H., Roeske, T., Baars, O., Moffett, J.W., Paul, M., Vance, D., Nakayama, N., Hsieh, Y.-T., Rember, R., Colman, A., Mor, P.C., Bull, A., Ryabenko, E., Twining, B.S., Brzezinski, M., Sanial, V., O'Sullivan, J., Wisotzki, A., Masque, P., Rintoul, S., Conway, T.M., Lacan, F., Zhao, Y., Stewart, G., Lu, Y., Peters, B., Nishiuchi, A., Baker, A.R., Zurbrick, C., Lamborg, C.H., John, S., Behrens, M.K., Pahnke, K., Thorne, K., Schauer, U., Cheng, H., Achterberg, E.P., Rutgers van der Loeff, M.M., Cutter, G.A., Kadko, D.C., Brumsack, H.-J., Dehairs, F., Semiletov, I., van Beek, P., Snaith, H., van Ooijen, J., Klar, J.K., Grissom, K., Morris, P.J., Scott, 
P., Friedrich, J., Aguliar-Islas, A., Rickli, J., Chamizo, E., Sherrell, R.M., Fitzsimmons, J.N., Ober, S., Charette, M.A., Boyd, P., Smethie, W.M., Watson, R., Maldonado, M.T., Landing, W.M., Rolison, J.M., Hammerschmidt, C., Zhang, P., Saito, M.A., Geibert, W., Rodellas, V., Slagter, H.A., Sohrin, Y., Deng, F., Roca-Martí, M., Kayser, R., Le Moigne, F.A.C., Zhang, J., Carrasco, G., LópezLora, M., Kim, T., Roshan, S., Sohst, B., Jones, J.L., Zheng, X.-Y., Hassler, C.S., George, E., Browning, T., Henderson, G.M., Bopp, L., Puigcorbé, V., Klunder, M., Buck, K.N., Ohnemus, D.C., Casciotti, K.L., Basak, C., Boyle, E.A., Mawji, E., Lechtenfeld, O.J., Anderson, R.F., Bown, J., Chever, F., Godoy, J.M., Gamo, T., Yoshikawa, H., Zunino, P., Zimmer, L.A., Horner, T.J., Mehic, S., de Baar, H.J., Henderson, P.B., Planchon, F., Shiller, A.M., Sedwick, P.N., Ganeshram, R.S., Wake, B., Jones, E.M., Stutsman, J., Venchiarutti, C., Edwards, R.L., Minami, T., Humphreys, M.P., Bowie, A., Buesseler, K., GarciaOrellana, J., Schallenberg, C., Abouchami, W., Moore, W.S., Pavia, F., Singh, S.K., Baskaran, M., Zheng, L., Jeandel, C., Weiss, D., Le Roy, E., Bluhm, K., Bowman, K., Swarr, G.J., Rauschenberg, S., Khondoker, R., Pena, L.D., Frank, M., Quay, P., Bridgestock, L., Voelker, A.H.L., Archer, C., Xue, Z., Buck, C.S., 2018. The GEOTRACES Intermediate Data Product 2017. Chem. Geol. 493, 210-223. doi:10.1016/j.chemgeo.2018.05.040

Shelley, R.U., Landing, W.M., Ussher, S.J., Planquett, H., Sarthou, G., 2018.

Regional trends in the fractional solubility of Fe and other metals from North Atlantic aerosols (GEOTRACES GA01 and GA03) following a two-stage leach. Biogeosciences 1-31. doi:10.5194/bg-2017-415

Shelley, R.U., Roca-Martí, M., Castrillejo, M., Masqué, P., Landing, W.M., Planquette, H., Sarthou, G., 2017. Quantification of trace element atmospheric deposition fluxes to the Atlantic Ocean ( $>40^{\circ} \mathrm{N}$; GEOVIDE, GEOTRACES GA01) during spring 2014. Deep. Res. Part I Oceanogr. Res. Pap. 119, 34-49. doi:10.1016/j.dsr.2016.11.010

Sieber, M., Conway, T.M., de Souza, G.F., Hassler, C.S., Ellwood, M.J., Vance, D., 2020. Cycling of zinc and its isotopes across multiple zones of the Southern Ocean: Insights from the Antarctic Circumnavigation Expedition. Geochim. Cosmochim. Acta 268, 310-324. doi:10.1016/j.gca.2019.09.039

Siebert, C., Nägler, T.F., Kramers, J.D., 2001. Determination of molybdenum isotope fractionation by double-spike multicollector inductively coupled plasma mass spectrometry. Geochemistry, Geophys. Geosystems 2. doi:10.1029/2000GC000124

Sunda, W., 1989. Trace metal interactions with marine phytoplankton. Biol. Oceanogr. 6, 411-442. doi:10.1080/01965581.1988.10749543

Sutton, J.N., de Souza, G.F., García-lbáñez, M.I., Rocha, C.L.D. La, 2018. The silicon stable isotope distribution along the GEOVIDE section (GEOTRACES GA-01) of the North Atlantic Ocean. Biogeosciences 15, 5663-5676. doi:10.5194/bg-15-5663-2018

Takano, S., Tanimizu, M., Hirata, T., Sohrin, Y., 2013. Determination of isotopic composition of dissolved copper in seawater by multi-collector inductively coupled plasma mass spectrometry after pre-concentration using an ethylenediaminetriacetic acid chelating resin. Anal. Chim. Acta 784, 33-41. doi:10.1016/j.aca.2013.04.032

Tonnard, M., Planquette, H., Bowie, A.R., van der Merwe, P., Gallinari, M., Desprez de Gésincourt, F., Germain, Y., Gourain, A., Benetti, M., Reverdin, G., Tréguer, P., Boutorh, J., Cheize, M., Menzel Barraqueta, J.-L., Pereira-Contreira, L., 
801

802

803

804

805

806

807

808

809

810

811

812

813

814

815

816

817

818

819

820

821

822

823

824

825

826

827

828

829

830

831

832

833

834

Shelley, R., Lherminier, P., Sarthou, G., 2020. Dissolved iron in the North Atlantic Ocean and Labrador Sea along the GEOVIDE section (GEOTRACES section GA01). Biogeosciences 14, 917-943. doi:10.5194/bg-17-917-2020

van Aken, H.M., Becker, G., 1996. Hydrography and through-flow in the northeastern North Atlantic Ocean: The NANSEN project. Prog. Oceanogr. 38, 297346. doi:10.1016/S0079-6611(97)00005-0

Vance, D., de Souza, G.F., Zhao, Y., Cullen, J.T., Lohan, M.C., 2019. The relationship between zinc, its isotopes, and the major nutrients in the North-East Pacific. Earth Planet. Sci. Lett. 525. doi:10.1016/j.epsl.2019.115748

Vance, D., Little, S.H., Archer, C., Cameron, V., Andersen, M.B., Rijkenberg, M.J.A., Lyons, T.W., 2016. The oceanic budgets of nickel and zinc isotopes: the importance of sulfidic environments as illustrated by the Black Sea. Philos. Trans. R. Soc. A 374. doi:10.1098/rsta.2015.0294

Vance, D., Little, S.H., de Souza, G.F., Khatiwala, S., Lohan, M.C., Middag, R., 2017. Silicon and zinc biogeochemical cycles coupled through the Southern Ocean. Nat. Geosci. 1-6. doi:10.1038/ngeo2890

Wang, R.M., Archer, C., Bowie, A.R., Vance, D., 2019. Zinc and nickel isotopes in seawater from the Indian Sector of the Southern Ocean: The impact of natural iron fertilization versus Southern Ocean hydrography and biogeochemistry. Chem. Geol. 511, 452-464. doi:10.1016/j.chemgeo.2018.09.010

Weber, T., John, S., Tagliabue, A., DeVries, T., 2018. Biological uptake and reversible scavenging of zinc in the global ocean. Science (80-. ). 361, 72-76. doi:10.1126/science.aap8532

Wheat, C.G., Mottl, M.J., Rudnicki, M., 2002. Trace element and REE composition of a low-temperature ridge-flank hydrothermal spring. Geochim. Cosmochim. Acta 66, 3693-3705. doi:10.1016/S0016-7037(02)00894-3

Williams, R.G., Roussenov, V., Follows, M.J., 2006. Nutrient streams and their induction into the mixed layer. Global Biogeochem. Cycles 20, 1-18. doi:10.1029/2005GB002586

Wyatt, N.J., Milne, A., Woodward, E.M.S., Rees, A.P., Browning, T.J., Bouman, H.A., Worsfold, P.J., Lohan, M.C., 2014. Biogeochemical cycling of dissolved zinc along the GEOTRACES South Atlantic transect GA10 at $40^{\circ} \mathrm{S}$. Global Biogeochem. Cycles 28, 44-56. doi:10.1002/2013GB004637

Zhao, Y., Vance, D., Abouchami, W., de Baar, H.J.W., 2014. Biogeochemical cycling of zinc and its isotopes in the Southern Ocean. Geochim. Cosmochim. Acta 125, 653-672. doi:10.1016/j.gca.2013.07.045

Zurbrick, C.M., Boyle, E.A., Kayser, R.J., Reuer, M.K., Wu, J., Planquette, H., Shelley, R., Boutorh, J., Cheize, M., Contreira, L., Barraqueta, J.L.M., Lacan, F., Sarthou, G., 2018. Dissolved $\mathrm{Pb}$ and $\mathrm{Pb}$ isotopes in the North Atlantic from the GEOVIDE transect (GEOTRACES GA-01) and their decadal evolution. Biogeosciences 15, 4995-5014. doi:10.5194/bg-15-4995-2018 


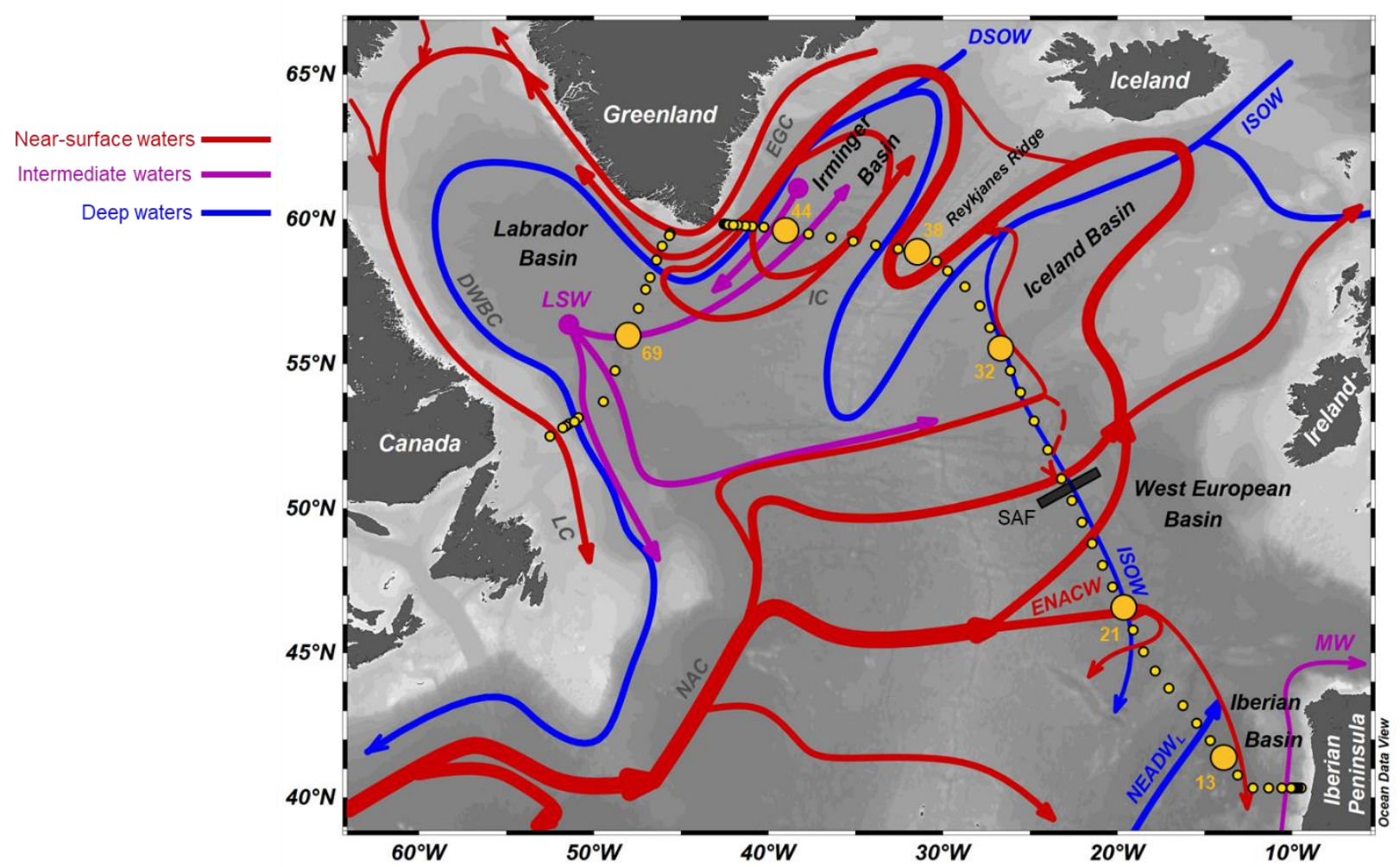

Figure 1: Schematic diagram of the large scale circulation in the North Atlantic, adapted from García-lbáñez et al., (2018). Abbreviations for the main hydrographic features indicated are as follows: Denmark Strait Overflow Water (DSOW), Iceland-Scotland Overflow Water (ISOW), Labrador Sea Water (LSW), Mediterranean Water (MW), North

East Atlantic Deep Water lower (NEADWL), East North Atlantic Central Water (ENACW), Labrador Current (LC),

841 East Greenland Current (EGC), Irminger Current (IC) and the North Atlantic Current (NAC), Subarctic front (SAF).

842 Yellow circles mark all stations sampled during GEOVIDE, with the large symbols representing the stations 843 discussed in this study. 


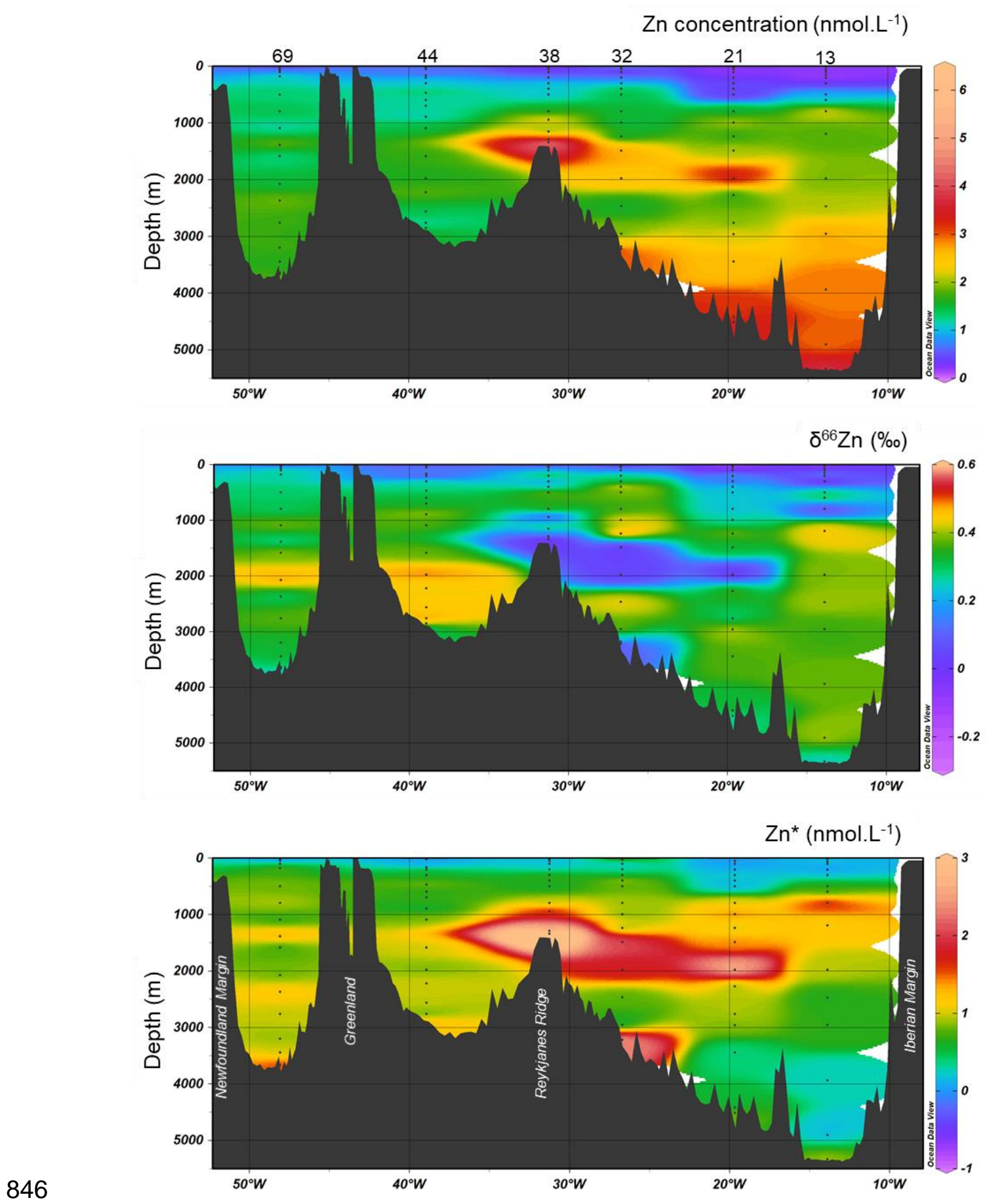

847 Figure 2: Zn concentrations, $\mathrm{Zn}$ stable isotope composition ( $\delta^{66} \mathrm{Zn}$ ) and $\mathrm{Zn}^{*}$ along the GEOVIDE transect. Black 848 dots represent sample locations. Station numbers are indicated at the top of the Zn concentration section. 

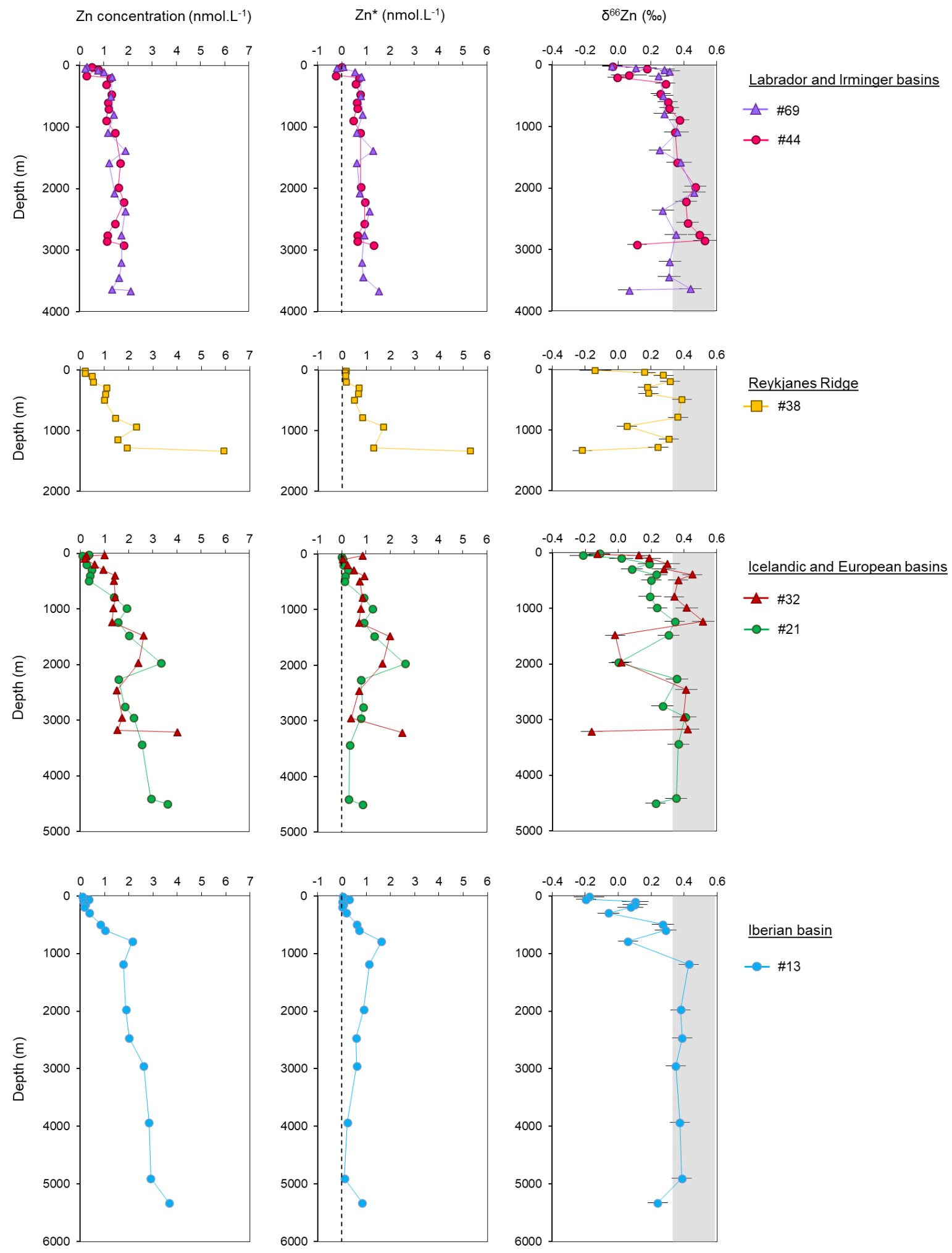
852 Fiqure 3: $Z n$ concentrations, $Z n^{*}$ and $\delta^{66} \mathrm{Zn}$ signatures for the stations of the GEOVIDE transect. The shaded
853 grey band shows the average $\delta^{66} \mathrm{Zn}$ in the deep ocean. 


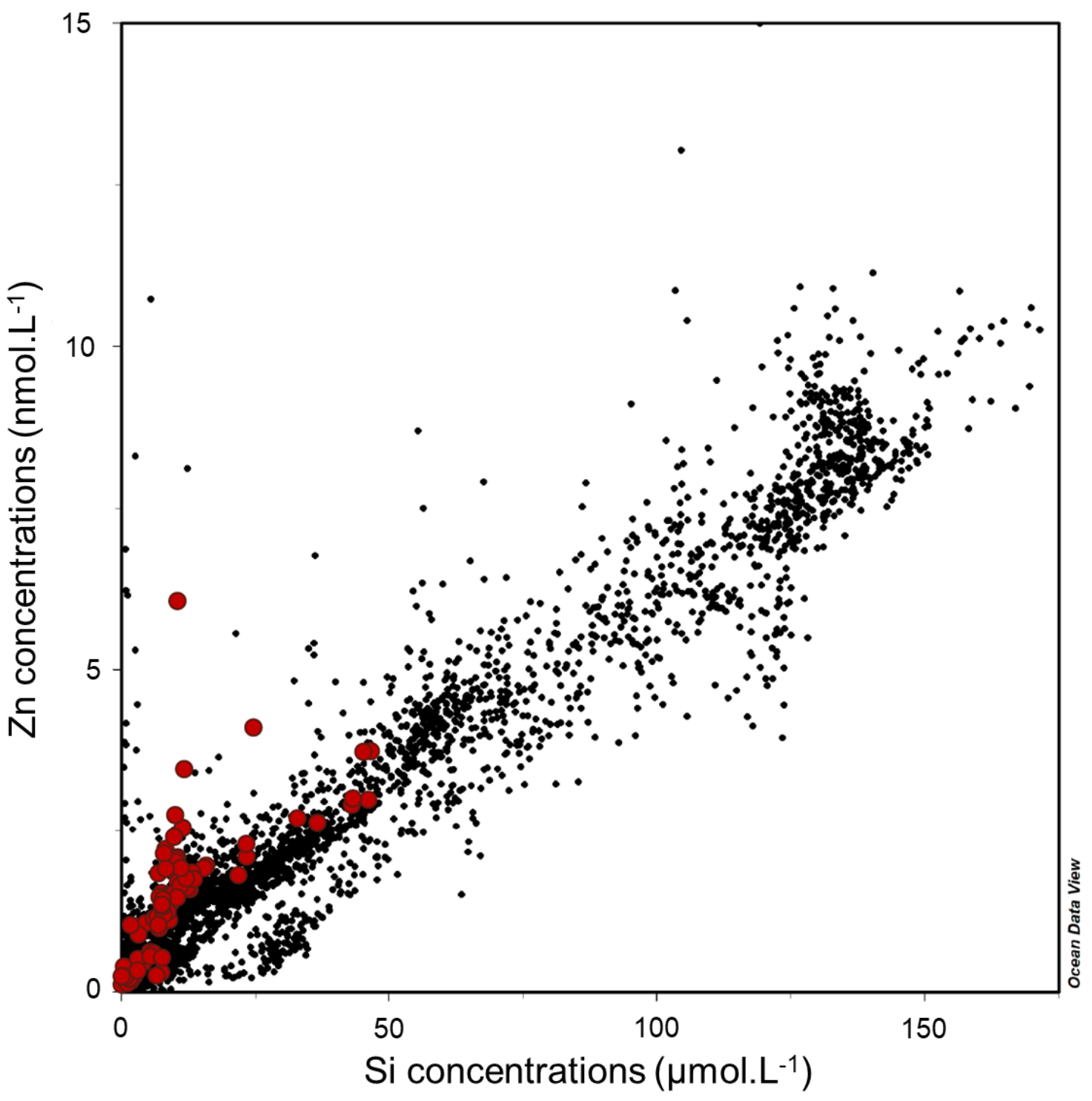

858 Figure 4: Zinc concentrations plotted versus Si concentrations for all samples in the GEOTRACES IDP 2017 859 (Schlitzer et al., 2018; black dots), with our data from GEOVIDE in red. 
861 Figure 5

a)

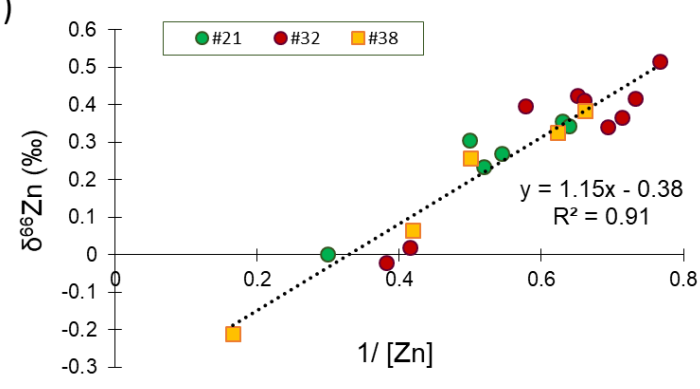

b)

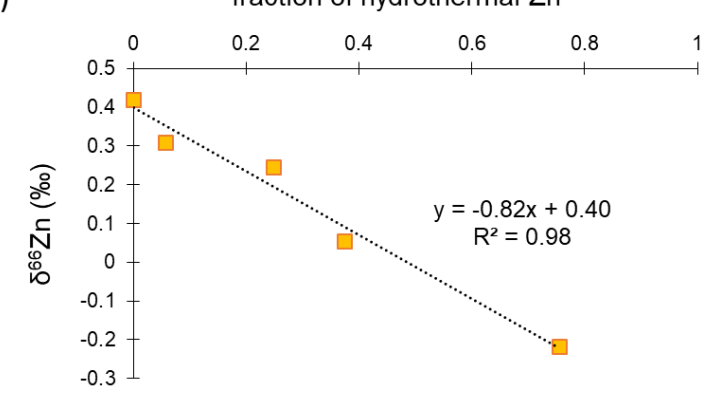

863 Figure 5: a) Zinc isotope composition $\left(\delta^{66} \mathrm{Zn}\right)$ plotted against $1 /$ [ $\left.\mathrm{Zn}\right]$ at depths between $1337 \mathrm{~m}$ (deepest data 864 point) and $700 \mathrm{~m}$ at Station 38, and between 3000m and 700m for Stations 21 and 32. b) Zinc isotope composition 865 as a function of the fraction of hydrothermal $\mathrm{Zn}$ (see explanations in the text) for all samples at Station 38 that are 866 influenced by the hydrothermal vent, and for background deep seawater $(x=0)$. The linear correlation provides an 867 estimate of the isotope composition of a hydrothermal end-member when $x=1\left(\delta^{66} \mathrm{Zn}=-0.42 \%\right)$. 
(a)

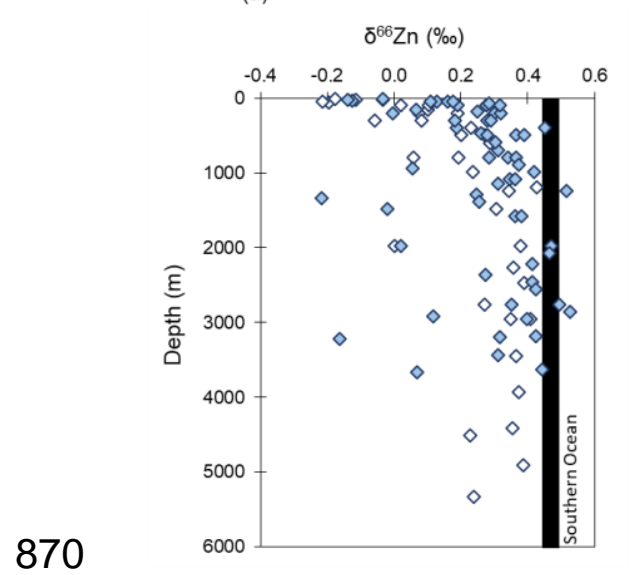

(b)

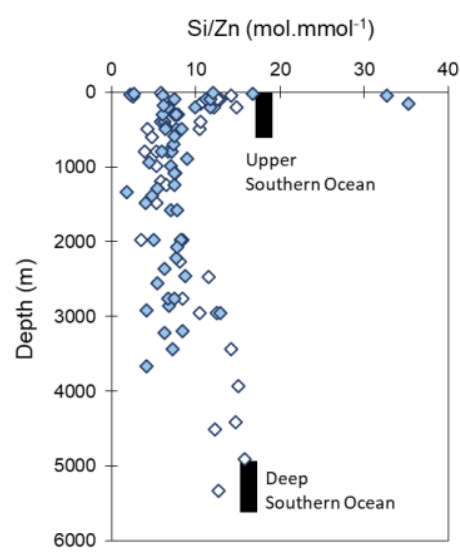
$\mathrm{NO}_{3}-1 \mathrm{Zn}\left(\mathrm{mol} . \mathrm{mmol}^{-1}\right)$

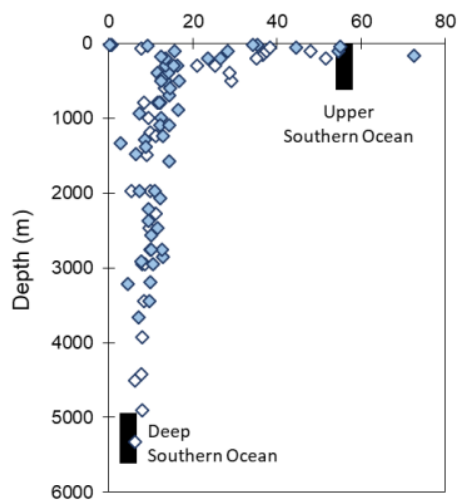

871 Figure 6: Depth distribution of (a) $\delta^{66} \mathrm{Zn}$, (b) Si/Zn and (c) $\mathrm{NO}_{3}{ }^{-1 / Z n}$ ratios for the GEOVIDE stations 13 and 21 east 872 of the Reykjanes Ridge, where abyssal waters of Southern Ocean origin dominate the deep ocean below $3000 \mathrm{~m}$ 873 (empty symbols) and for the GEOVIDE stations 32, 38, 44 and 69 (blue symbols). The black rectangles show the 874 average $\delta^{66} \mathrm{Zn}$, Si/Zn and $\mathrm{NO}_{3} / \mathrm{Zn}$ ratios of the upper and deep Southern Ocean. While the deep North Atlantic has $875 \mathrm{Zn}$ isotope compositions and macronutrient/Zn ratios that are very close to the ultimate source of these water 876 masses in the Southern Ocean, the upper ocean shows low Si/Zn, low $\mathrm{NO}_{3}{ }^{-} / \mathrm{Zn}$ and light $\mathrm{Zn}$ isotopes that are most 877 consistent with a source of isotopically light $Z n$. 
(a)

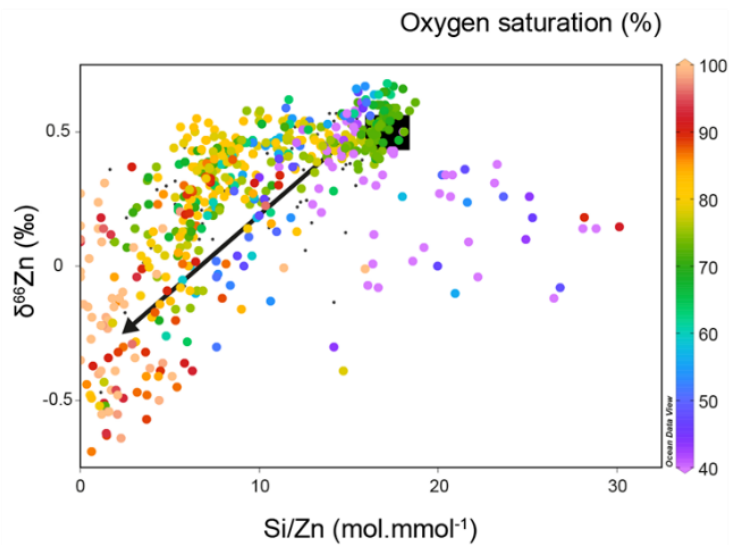

(b)

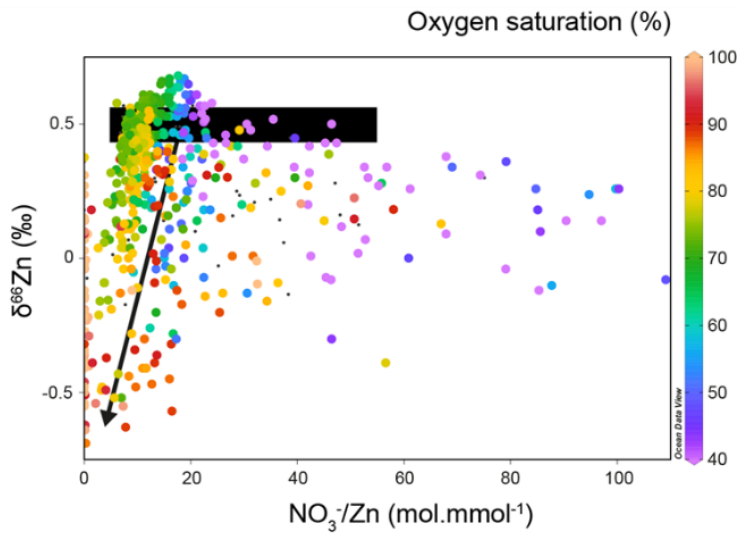

Figure 7: $\delta^{66} \mathrm{Zn}$ plotted against (a) Si/Zn and (b) $\mathrm{NO}_{3}{ }^{-} / \mathrm{Zn}$ ratios for the North Atlantic (GEOVIDE and GA03 cruises; this study and Conway and John, 2014). Data are colour-coded for oxygen saturation. The black rectangles show the average $\delta^{66} \mathrm{Zn}$ and concentration ratios for the Southern Ocean. Black arrows indicate addition of isotopically light $\mathrm{Zn}$ relative to major nutrient. The intercepts of the black arrows, at $\mathrm{NO}_{3}-\mathrm{Zn}$ and $\mathrm{Si} / \mathrm{Zn}=0$ constrain the source of added $\mathrm{Zn}$ to have a $\delta^{66} \mathrm{Zn}$ of around $-0.5 \%$. 


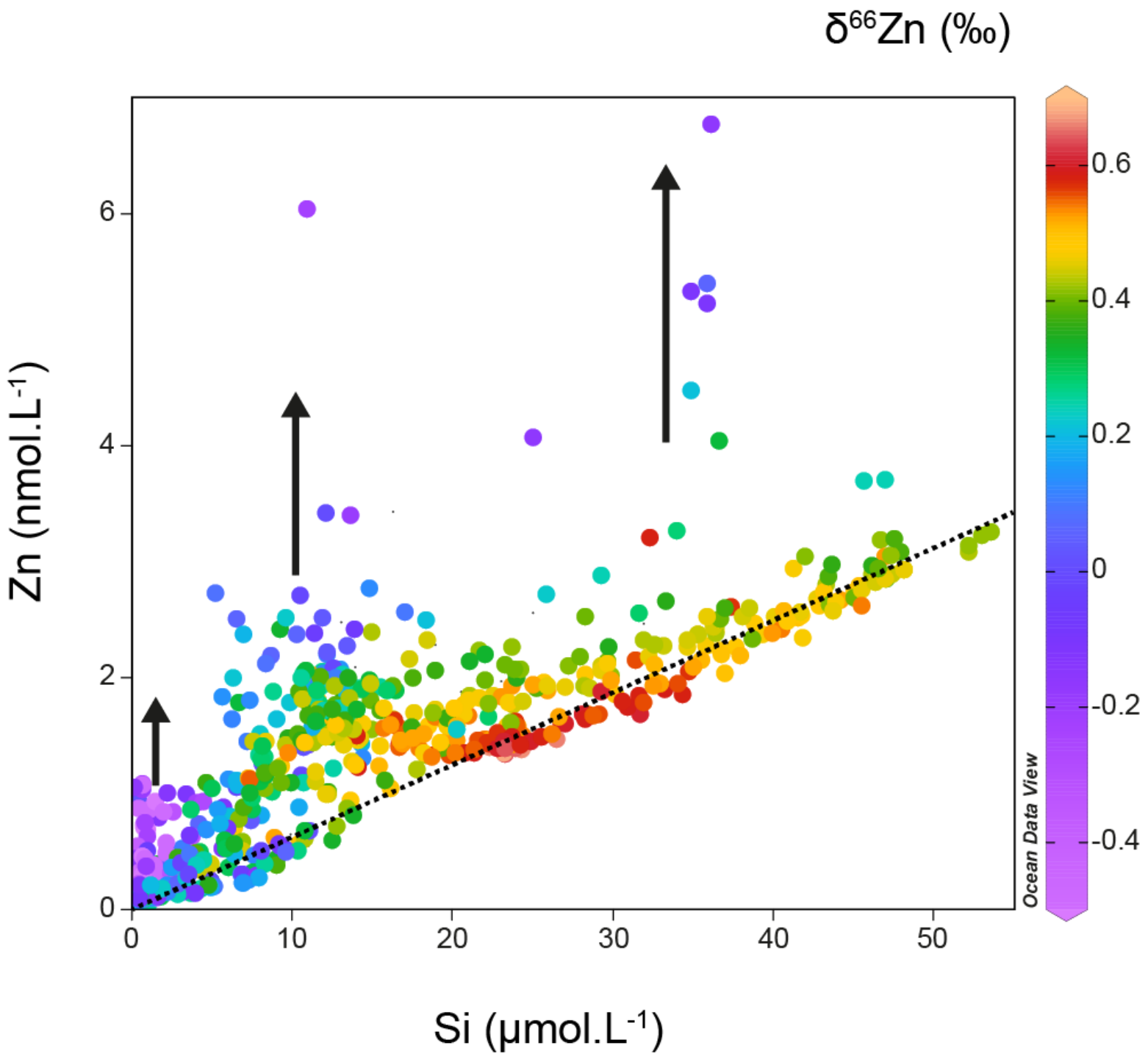

Fiqure 8: Zinc concentrations against Si concentrations, with colours indicating Zn isotope composition, for the entire North Atlantic (GEOVIDE and GA03 cruises; this study and Conway and John, 2014). Black arrows indicate additions of $Z n$ relative to Si. The dotted line represents the global Zn-Si relationship (GEOTRACES IDP 2017).

892

893 